\title{
EDUCATIONAL ATTAINMENTS AND HOUSEHOLD CHARACTERISTICS IN TANZANIA*
}

\author{
by Samer Al-Samarrai and Tessa Peasgood ${ }^{\#}$
}

\author{
IDS Working Paper 49
}

\begin{abstract}
Summary
This paper uses multivariate regression techniques to analyse household survey data collected in rural Tanzania in 1992 in a joint research project by TADREG (Tanzania Development Research Group) and the University of Dar es Salaam. It focuses on how information collected on household and individual characteristics affect whether or not a child goes to primary school, completes primary and attends secondary. The regression analysis clearly shows substantial intra household differences between the way in which household characteristics affect outcomes for boys and girls, and how mothers' and fathers' influence over resource decisions differently affect outcomes. For example, when looking at the decision as to whether to enrol in primary school, fathers' education has a greater influence on boys whereas mothers' primary education has a greater influence on girls. Furthermore, married mothers' education can increase the probability of girls enrolling in secondary school by 9.7 per cent for primary education and a further 17.6 per cent for secondary, while having no significant effect on the enrolment of boys. These results imply that mothers have a relatively stronger preference for their daughters' education and that their education affords them either increased household decision-making power or increased economic status.
\end{abstract}

\footnotetext{
* The authors would like to thank all members of the FAWE Gender and Primary Schooling in Africa Project, Barry Reilly and Brian Cooksey for assistance with this paper.

\# Samer Al-Samarrai is a Research Officer at IDS; Tessa Peasgood is a former IDS Research Officer now working at the Research and Development Support Unit, of the Institute of Health and Community Studies. The authors can be contacted at the Institute of Development Studies, University of Sussex, Brighton BN1 9RE, UK. Tel: +44 (0) 1273606261 Fax: +44 (0) 1273621202 E-mail: S.M.Al-Samarrai@ sussex.ac.uk TPeasgoo@bournemouth.ac.uk
} 


\section{Preface}

The work presented in this paper is part of a research Programme on Gender and Primary Schooling in Africa which is being conducted in three African countries under the auspices of the Forum for African Women Educationalists (FAWE). The main aims of the project have been to examine the causes of low enrolments, persistence and performance of girls relative to boys and to identify the most promising policy options to facilitate the universal enrolment of children in primary schools.

This Working Paper uses data collected by the Tanzania Development Research Group (TADREG) to investigate how household and individual characteristics affect whether or not a child goes to school.

Christopher Colclough

Programme Director 


\section{INTRODUCTION}

This paper uses multivariate regression techniques to analyse household survey data collected in rural Tanzania in 1992 in a joint research project by TADREG (Tanzania Development Research Group) and the University of Dar es Salaam. It focuses on how information collected on household and individual characteristics can be used to determine whether a child goes to primary school, completes primary and attends secondary. This paper begins with some background information on the education sector in Tanzania which outlines the provision of education as it relates to the respective cohorts within the household sample. The following section discusses the framework used for the empirical work. Section 3 describes the data sample, raising issues related to sampling and problems with the data set. Section 4 reports the regression results, which are interpreted and placed in the context of other research.

Tanzania remains one of the world's poorest countries with a per capita income estimated at US\$140 in 1994 . Over 80 per cent of the 28 million ethnically diverse population live in rural areas, with considerable inequities in terms of living standards between rural and urban areas; 43 per cent of the rural population and 19 per cent of the urban population live below the poverty line (World Bank 1995b). The economy is predominantly agrarian, with agriculture comprising over 80 per cent of all employment. Following strong government commitment to developing human resources, social indicators (including educational attainment) followed an upward trend between 1960 and 1986; however, economic difficulties resulted in a reversal of this trend and Tanzania is now placed poorly in relation to other SSA countries.

Prior to independence access to basic education in Tanzania was scarce, with wide inequities in terms of race, region and gender. Many primary schools had been established by Christian missionaries, hence providing Christians with favourable education access. In 1947 under 10 per cent of the school-age population was enrolled in primary school. At the secondary level under one per cent of the school-age population was enrolled and no females had ever progressed beyond the primary level (Cameron and Dodd 1970: 102, 104).

Immediately after independence in 1961 education policy focused firstly on strengthening the secondary level, which was to expand in line with manpower planning requirements, to train local people for the public sector in order to replace the expatriate work force, and secondly on providing a basic education system appropriate for the emerging Socialist Tanzania. A more agriculturally-based primary curriculum was introduced following the Arusha Declaration in 1967 with a new policy of Education for Self-Reliance (ESR) encouraging each school to contribute to its own upkeep through income raising activities. Primary schooling was planned to expand gradually so as to achieve UPE (Universal Primary Education) by 1989. The decision to abolish 
school fees at primary level in 1973 was expected to support this expansion. However, the implementation date for UPE was brought forward to 1977 in the Musoma Resolution of 1974 on the grounds that resource constraints would always be operative and delaying universal provision of basic education was politically inconsistent for a socialist government. The Musoma Resolution sought to make primary education compulsory, universal and terminal. Consequently, in 1978 an Education Act was passed which made primary enrolment and attendance between the ages of seven and 13 compulsory. ${ }^{1}$ Contravention of this Act led to some parents being fined or even imprisoned.

The number of primary pupils increased almost immediately after the Musoma Resolution, with enrolments increasing four fold during the 1970s and continuing to rise until 1983. The expansion at primary level was not, however, matched by a similar expansion at secondary level. Consequently despite a small rise in the absolute numbers of secondary school enrolees, the percentage of standard VII leavers continuing to secondary school plummeted - falling from 36 percent in 1961 to 19 per cent in 1967 and to only 7 per cent in 1980 (Knight and Sabot 1990). The proportion rose to about 15 per cent by the early 1990s following a change in policy regarding restrictions on the private/NGO sector in the mid 1980's. Prior to 1984, the private secondary school operations were severely restricted by government. By consequence, the percentage of Form I pupils in non government secondary schools rose from 7 per cent in 1960 to 29 per cent in 1970 to 43 per cent in 1980 and 60 per cent in 1992.

However, the dramatic and rapid expansion at primary level, combined with declining national economic performance and constrained government finance, had detrimental consequences in terms of education quality. Parents began to complain of illiterate primary graduates, the benefits of schooling were questioned, enrolment rates declined and drop-out rates increased. The GER declined from a peak of 96 per cent in 1983 to an estimated 73.5 per cent in 1990.

In efforts to address the economic crisis the government turned towards more free market policies adopting a structural adjustment programme which included a major currency devaluation, the curtailment of government expenditure, civil service retrenchment and extensive privatisation. In line with these economic changes the education sector began to encourage private sector involvement and seek a broader resource base for the financing of education. The changing economic environment would be expected to alter the costs and future benefits of education. By the mid 1990s households faced rising costs at primary and secondary levels. Low enrolments and high drop-outs continue to characterise the primary education system, and rising direct costs to households have raised fears that enrolments may decline further (IDS and MOEC 1996)

${ }^{1}$ Education Act Number 25 of 1978 was amended in 1995 to ensure compulsory enrolment of all seven year olds. 
although there has been strong government commitment to tackling the problems of the education sector (Primary Education Master Plan 1995a).

When the TADREG rural household survey was carried out in 1992, there still remained substantial uncertainty regarding education policy and teachers wages were considerably below the level necessary to ensure their adequate motivation (Cooksey et al 1991). Research indicated widespread dissatisfaction with education provision (see Omari \& Mosha 1987, Sumra 1993) and revealed large inequities between boys' and girls' in performance at all levels and access to post primary opportunities (Mbilinyi et al 1991).

In this context, the significant changes in the supply of education since 1960, influenced by radical changes in government policy, economic fortunes and by public perceptions of the value of education, are likely to be reflected in the educational attainment of different cohorts. Society's educational attainments are dependent on both supply conditions and the willingness and ability to pay for education at the level of the household. Household education decisions are taken within this supply context and actual attendance at different levels of education are dependent on both household demand and the availability of places.

\section{MODEL SPECIFICATION}

\subsection{Theoretical Framework}

Household schooling decisions are determined by an interaction of social, cultural and economic factors working through power relations within the household. One can view education, conceptually, as both a consumption and an investment good. Parents educate their children so that their children and their children's children will have better life chances, and because they enjoy having literate and educated children. However, parents also invest in their children to ensure that their offspring will be best placed to support them in later life.

A household production function approach has been widely used in the literature to model household schooling decisions (Tansel 1993, Chernichovsky 1985, Duraisamy 1992). These models imply that there is an optimal investment in education for each child that equates the present value of expected benefits and costs to the household of educating their children. Costs are incurred through the duration of a child's schooling and include direct costs (e.g. fees and uniforms), opportunity costs of the child's time (those activities foregone whilst at school and travelling to school e.g. helping in the home or on the household farm) and other non-monetary costs such as the possible increased risk of getting pregnant if girls attend school. Where primary 
education is compulsory, as in Tanzania, the cost of going to school can be seen to be the direct, opportunity and other non-monetary costs of going to school minus the costs incurred by not going to school. The cost of not going to school is the penalty imposed if the child is found not to be attending school weighted by the probability of the child being caught out of school. ${ }^{2}$ This probability is dependent on how strictly the law is adhered to, which is likely to vary by locality. Benefits to the household from education will depend on many factors including the amount of remittances the family are expecting from their children once they have left home, the probability that their children will get work, the way individual children can translate education into improved productivity and the time preferences of the household. Where women suffer from differential access and wage discrimination in labour markets this is likely to be detrimental to the expected household return to investing in girl's education. Also, if girls marry out of their own family into their husband's family the parents may not be able to benefit from the returns to their daughter's schooling.

Although there may be an optimal investment in education, the presence of constraints may mean that this optimum is unobtainable for some households; how close to this optimum the household gets will depend on the characteristics of the individual household. For example, because costs of education are incurred before benefits are recouped some households may not have the resources to pay for schooling and may be unable to borrow to finance their children's schooling. The extent to which this constraint inhibits investment in education is likely to be related to the parent's education, with more educated parents being less credit-constrained than less educated parents, ceteris paribus. The position of the child in relation to other siblings in the household may also affect the schooling decision. On the one hand, children born into the family early, when resources are stretched over fewer members of the household, may be more likely to go to school. On the other hand, a child born into the family later may have lower opportunity costs than an earlier born sibling because the need to look after other siblings within the household would be reduced.

Education can also be seen as a consumption good in two ways. Firstly, educated children may directly enhance their parents' utility and secondly, there may be non-pecuniary benefits to education for the acquiring child (i.e. the child's current utility may be enhanced by going to

${ }^{2}$ This implies a conventional cost benefit calculation such as:

$$
\sum_{t=s+1}^{n} \frac{B_{t}}{(1+r)^{t}}=\sum_{t=0}^{s} \frac{C_{t}}{(1+r)^{t}}
$$

where $\mathrm{B}$ are the benefits, $\mathrm{r}$ the interest rate, $\mathrm{n}$ the working years of the child and $\mathrm{s}$ the years the child is at school.

$\mathrm{C}=$ costs associated with going to school - (probability of being caught out of school * the penalty imposed on those flouting the education law). 
school). When education is seen in this way the households' preferences for educated children will play a part in the decision to send their children to school. This is again likely to be related to the level of education of the parents. Preferences for schooling of boys and girls are formed in the context of social and cultural norms, and it is likely therefore that preferences will be gender specific and household attributes will have a differing impact on the schooling decision for boys and girls.

The decision to send a child to school may be made by either parent or both. In the household production function approach it is assumed that a combined household utility function is maximised and resource allocation decisions are made through the 'benevolent dictatorship' of the household head (Becker 1981). There has been much evidence to suggest that this assumption does not hold and that resource allocation decisions are made by other members of the household as well as the household head (Haddad et al 1994, Kabeer 1991). Bargaining approaches to household decision-making do not assume that resource allocation decisions are made through a process of bargaining between individual members of the household. The stronger the bargaining power of a family member the more influence they will have on resource allocation decisions (Sen 1990). Bargaining power will be dependent on an individual's characteristics, and therefore the attributes of other household members, as well as the household heads', will be relevant when looking at schooling decisions. For example, if the mother is educated this is likely to improve her bargaining power within the household and her preferences for educated children will play a larger role in the decision to send her children to school.

This paper uses the characteristics of the household to assess the probability that a child has attended school, controlling for village-specific effects. The household schooling decision is analysed at three stages of the schooling system in Tanzania. The three decisions are whether the household sends the child to primary school or not, whether the child completes primary school conditional on the child having entered the primary system and, finally, whether the child attends secondary school given that the child has already completed the primary cycle.

\subsection{Empirical Specification}

The three schooling decisions, outlined above, are analysed in this paper using a standard logit model. ${ }^{3}$ It is assumed that we have a standard regression model such as:

$$
y_{i}^{*}=\beta_{0}+\sum_{j=1}^{l} \beta_{j} x_{i j}+\sum_{k=l+1}^{q} \beta_{k} z_{i k}+\sum_{m}^{15} \beta_{m} v_{i m}+u_{i}
$$

\footnotetext{
${ }^{3}$ For a complete description of the uses of limited dependent variables and qualitative variables in econometrics see Maddala (1983).
} 
where $y_{i}^{*}$ is an unobserved latent variable, the $x_{i j}$ are household characteristic variables, $z_{i j}$ are child specific variables and $v_{i m}$ are 15 village specific dummies. The value of $y_{i}^{*}$ can be interpreted as the desire and/or ability of the parents to send a particular child to school. What is observed is a dummy variable, $y_{i}$, that is equal to one when the child goes to school and equal to zero otherwise such that:

$y_{i}= \begin{cases}1 & \text { if } y_{i}^{*}>0 \\ 0 & \text { otherwise }\end{cases}$

The probability, $P_{i}$, that the child goes to school (i.e. $y_{i}=1$ ) is therefore:

$$
P_{i}=F\left(\beta_{0}+\sum_{j=1}^{l} \beta_{j} x_{i j}+\sum_{k=l+1}^{q} \beta_{k} z_{i k}+\sum_{m}^{15} \beta_{m} v_{i m}\right)
$$

where $\mathbf{F}$ is the cumulative distribution function of the error term. These probabilities form the basis of the likelihood function which is used to obtain estimates of the parameters in equation 1 above. For ease of computation of the model outlined above a logistic distribution has been assumed for the error term.

The effects of any of the explanatory variables on the probability that a particular observation belongs to either one of the two groups (i.e. whether a child enrols at school or not) are known as marginal effects (for continuous explanatory variables) and impact effects (for dummy explanatory variables). ${ }^{4}$ These are calculated for the variables included in equation 1 and are reported in the results section of this paper.

Two methods can be used to analyse the differential impact of household attributes on boys' and girls' education discussed in the previous section. Firstly, two separate regressions can be run for boys and girls with the coefficients of these regressions relating specifically to the effects for boys and girls separately. This approach assumes that all variables have a differing impact. A second approach is to pool the girls' and boys' samples and allow for different effects on specific variables using slope dummies (equal to one if the child is female, zero otherwise). ${ }^{5}$ Separate

\footnotetext{
${ }^{4}$ The marginal and impact effects are calculated using the mean of the probabilities of each case. ${ }^{5}$ For a general discussion of the use of slope dummies see Greene(1993) or Maddala (1992).
} 
coefficient estimates for boys and girls can be recovered using this method and significance tests on these can be carried out. Additionally, the pooled regression provides a test for the significance of the difference between the male and female coefficients. ${ }^{6}$

This paper has adopted the second approach and initially pooled regressions with slope dummies for most of the explanatory variables were estimated. Some of the slope dummies were dropped due to their insignificance and a more parsimonious model, for each regression, was estimated. ${ }^{7}$

\section{DESCRIPTION OF THE DATA}

\subsection{Background}

The data used in this paper are taken from research jointly conducted by TADREG and the University of Dar es Salaam. Field work was undertaken during July-September 1992 by 16 sociology and other social science students, supervised by Dr George Malekela and Dr Jo Lugalla under the co-ordination of Dr Brian Cooksey with funding from SIDA. Following the field work, extensive qualitative material and basic statistics from the data were compiled and analysed considering parental and community views of education provision and motives for opting in or out of the education system. Details of these findings can be found in Parents Attitudes and Strategies Towards Education in Rural Tanzania, TADREG 1993.

The sample consisted of 16 villages, which were the home villages of second year students from the Department of Sociology, at the University of Dar es Salaam. These villages represent a reasonable coverage of the country being in 12 of the country's 20 regions and in 15 different districts, covering agricultural, agropastoral and pastoral communities. They cannot, however, be taken as representative at the district, region or country level. For this reason any relationships arising within the multivariate analysis should be taken as describing this particular sample. Being the home village of university students, who are an educationally elite minority, these villages are likely to experience above average educational performance.

The primary schools within these sample villages are significantly larger than the national average, having a mean number of pupils of 576 compared with a national mean of 335 in 1991 (TADREG 1993: 11). Despite research findings of dilapidated conditions in most of these schools and absence of equipment and supplies (TADREG, 1993:13), evidence which suggests

\footnotetext{
${ }^{6}$ This is a test of the significance of the coefficient on the slope dummy.

${ }^{7} \mathrm{~A}$ likelihood ratio test was carried out to test whether the pooled regression was a better specification than using two gender-disaggregated regressions. The test was not rejected implying that the pooled regression provided a better specification.
} 
that larger schools are usually of better quality (IDS and MOEC 1996) implies that the schools in these areas are still likely to be better than most schools in the country. This is supported by the fact that the number of selections into public secondary school (based on performance in a nationally-set Primary School Leaving Exam in conjunction with district, gender segregated, quotas) for the previous 10 years within the sample schools was 10 per cent above the average to be expected, based on school size. Consequently, it may be assumed that the higher quality primary provision may cause, or itself may have been caused by, a relatively high demand for education within the sample villages.

Education supply within the sample villages was found to be less affected by the UPE drive than is reported for many in Tanzania. Access and quality differences at primary level have been well reported between urban and rural areas (e.g. TADREG 1991, Komba 1995). While this sample is solely rural, hence removing some of the potential influence of supply differences, large variations are still likely to exist in terms of local supply conditions. In addition to the physical supply of education facilities, variations in terms of the strength of the local village government and school committee in implementing the compulsory education legislation, school level financial contributions, gender sensitivity of the teachers and village attitudes towards the importance of education for girls and boys may all influence the probability of school attendance and completion. The use of village control dummies accounts for the effect of these supply differences and while there is insufficient information regarding supply conditions in each village to draw any conclusions from the coefficients on these village dummies, the results in Table A2 in the appendix interestingly show circumstances where conditions within the same village had significantly different effects on boys and girls.

In total 702 household heads were interviewed, providing information on 3,345 family members. ${ }^{8}$ Within each village, interviewers sampled up to 45 mature households, i.e. only those households with some children above the school starting-age. A random stratified sample, in proportion to the frequency of mature male and female-headed households in the village, was collected, resulting in one fifth of selected households being female-headed. ${ }^{9}$

Information was collected on a variety of household variables including sex, age, education and occupation of the household head, age and education of the spouse, the number of children and dependants, ethnicity, religion, and type of marital relationship. The variables used in the regression analysis are listed in Table 1.

\footnotetext{
${ }^{8}$ Although the initial sample included 3,345 cases, due to missing values for some variables the sample used for the regression analysis was substantially reduced.

${ }^{9}$ The Human Resource Development Survey (HRDS) in 1993/94 found that 15 per cent of households interviewed were female headed (World Bank 1995).
} 
Table 1: List of Variable Names

\begin{tabular}{ll}
\hline Parameter & Description \\
\hline C & Constant \\
Village Dummies & Reference category is if the household came from Chimala village, Mbeya Rural District in Mbeya \\
VILL2 & 1 if household came from Ilolo village, Dodoma Rural Disitrict in Dodoma \\
VILL3 & 1 if household came from Kilole village, Korogwe District in Tanga \\
VILL4 & 1 if household came from Langiro village, Mbinga District in Ruvuma \\
VILL5 & 1 if household came from Longido village, Monduli District in Arusha \\
VILL6 & 1 if household came from Mabogini village, Moshi Rural District in Killimanjaro \\
VILL7 & 1 if household came from Malinyi village, Ulanga District in Morogoro \\
VILL8 & 1 if household came from Mbalizi I village, Mbeya Rural District in Mbeya \\
VILL9 & 1 if household came from Mihma Kitangiri village, Mwanza Rural District in Mwanza \\
VILL10 & 1 if household came from Mkididiri village, Ngara District in Kagera \\
VILL11 & 1 if household came from Mpui village, Sumbawanga District in Rukwa \\
VILL12 & 1 if household came from Mrara village, Babati District in Arusha \\
VILL13 & 1 if household came from Ndago Nguvumali village, Iramba District in Singida \\
VILL14 & 1 if household came from Nyandekwa village, Kahama District in Shinyanga \\
VILL15 & 1 if household came from Sokon II village, Arumeru District in Arusha \\
VILL16 & 1 if household came from Talatala village, Kyela District in Mbeya
\end{tabular}

\section{Ethnic Dummies}

TRIBE10

TRIBE14

1 if household is from Hehe tribe

1 if household is from Kinga tribe

TRIBE33 1 if household is from Ngindo tribe

TRIBE34 1 if household is from Ngoni tribe

TRIBE42 1 if household is from Pare tribe

Religion Set of dummy variables with the reference category being Christian households

MUSLIM $\quad 1$ if household is Muslim

PAGAN $\quad 1$ if household is Pagan

Occupation Set of dummy variables with the reference category being farming household head

OCCHD2 1 if cattle rearing is main occupation

OCCHD3 1 if trade is main occupation

OCCHD4 1 if household head is in paid employment

OCCHD5 $\quad 1$ if household head is in other occupations than those listed above

Marriage Status Set of dummy variables with the reference category being monogamous two parent family

TYPMRR $\quad 1$ if household head was in a polygamous marriage

MARIT2 1 if household head was divorced

MARIT3 1 if household head was widowed

MARIT4 1 if household head was single

Education Set of dummy variables with the reference category being those heads or spouses with no formal education

HDPRIM $\quad 1$ if household head completed primary

HDSEC $\quad 1$ if household head completed secondary

SPOPRIM $\quad 1$ if spouse completed primary

SPOSEC $\quad 1$ if spouse completed secondary

ILLIT $\quad 1$ if household head was illiterate

Other Variables

AGEHD Age of the household head

HEADSEX Sex of the household head. 1 if female

POSKID Position of the child in the family. For the first born child POSKID=1

PSKDSQR Position of the child in the family squared

NOCDHH Number of children in the household

NCDHSQR Number of children in the household squared

AGEKID Age of child 


\subsection{Characteristics of the Sample}

The household head may be either male or female; 16 per cent of the sample used for the regression analysis are from female-headed households. The variables on spouse's education are only included where the head was male, hence ensuring that this variables was picking up the impact of mothers only. ${ }^{10}$ Table 2 shows some basic characteristics of the sample, disaggregated by male and female heads.

Table 2: Means of Selected Descriptive Variables, by Gender of Household Head

\begin{tabular}{|c|c|c|c|}
\hline Household heads & Male heads & Female heads & Sample \\
\hline Average age of head (years) & 55.6 & 49.7 & 54.6 \\
\hline \multicolumn{4}{|l|}{ Religion (\%) } \\
\hline Muslim & 14.9 & 15.6 & 15.0 \\
\hline Pagan & 6.1 & 9.2 & 6.6 \\
\hline Christian & 79.0 & 75.2 & 78.4 \\
\hline \multicolumn{4}{|l|}{ Main Occupation (\%) } \\
\hline Farmer & 77.6 & 79.6 & 78 \\
\hline Cattle owner & 6.5 & 1.1 & 5.6 \\
\hline Trade & 4.2 & 10.4 & 5.2 \\
\hline Employed & 8.2 & 1.7 & 7.1 \\
\hline Other & 3.5 & 7.2 & 4.1 \\
\hline Average no. of children in household & 6.9 & 5.9 & 6.7 \\
\hline \multicolumn{4}{|l|}{ Type of marriage $(\%)$} \\
\hline Is/was a polygamous marriage & 27.3 & 5.7 & 23.7 \\
\hline Still married & 95.6 & 14.5 & 82.4 \\
\hline Divorced & 1.9 & 21.7 & 5.1 \\
\hline Widowed & 2.2 & 41.6 & 8.6 \\
\hline Single & 0.3 & 22.2 & 3.9 \\
\hline \multicolumn{4}{|l|}{ Heads education level (\%) } \\
\hline Have basic literacy & 78.9 & 69.8 & 77.2 \\
\hline Have primary education & 71.0 & 57.2 & 68.7 \\
\hline Have secondary education & 8.3 & 2.0 & 7.3 \\
\hline \multicolumn{4}{|l|}{ Spouses education level (\%) } \\
\hline Have primary education & 52.0 & - & - \\
\hline Have secondary education & 2.2 & - & - \\
\hline
\end{tabular}

Note: These means are weighted by the number of children in the household and exclude cases with any missing data, therefore they may vary from those reported in TADREG 1993

The sample households were categorised into 58 different ethnic groups, although these were concentrated in 13 groups and in general the sample villages were ethnically homogeneous. The villages in the sample were predominantly Christian (78 per cent of the offspring being from

${ }^{10}$ Where the head is female and still married the husband's education level has not been accounted for. This sub sample is extremely small and the exclusion of the husband's education level is unlikely to affect the results. 
Christian households) which is in contrast to Tanzania (mainland) where approximately 35 per cent of the population is Muslim and 20 per cent belong to other non-Christian religions. ${ }^{11}$ Within this sample Muslim households are fairly evenly spread between the different villages.

Female-headed households display slightly different characteristics to male-headed households. On average female-headed households have one less child, are on average 6 years younger, and are more likely to be involved in trading and are less likely to be employed. The main difference occurs in the type of marriage, with almost all male heads and only 14.5 per cent of female heads still married. Nearly half of the female heads are widowed, another 21.7 per cent through divorce and 22.2 per cent have never married. The socio economic status of female-headed households in many African countries is lower than that of male-headed households as a consequence of the unequal access women have to means of production. Exclusion from land in Tanzania has been found to result in economic vulnerability of divorced and widowed women (Swantz, 1985). The Tanzanian Demographic Health Survey between October 1991 and March 1992 found that mothers who were divorced, had never married or were widowed were significantly poorer than married mothers (Katapa and Astone 1993 cited in Kaijage and Tibaijuka 1996: 24).

Within each household detailed information was gathered on the education status of their seven eldest children. These offspring vary in age from seven to 56, with over three quarters of the sample falling between the ages of 11 and 30 . Male and female enrolment rates at primary and secondary level in the sample are fairly similar, although the net enrolment rate (NER) for girls exceeds that for boys until the age of 15 where the reverse is true. ${ }^{12}$ The NER for 7-13 year olds (the official primary school-age) for the sample is over 80 per cent which far exceeds national estimates of 54.2 for $1992^{13}$. This may result from the better than average education provision and demand in the sample villages, or alternatively from the fact that only mature households are sampled and enrolment ratios may be higher in these households. ${ }^{14}$

Of all the offspring for which information was collected, 40 per cent are still studying; the remainder have either terminated their formal education or, in the case of some younger children, are yet to enrol at school. From Table 3 it is clear that 7-9 year olds have a lower tendency to enrol in school than 10-13 year olds. Late enrolment is a major problem within Tanzania, the

\footnotetext{
${ }^{11}$ Estimates for the religious breakdown of the country vary substantially as religious categorisations are no longer used officially. People of certain religious denominations tend to be clustered, e.g. the Coast region is predominantly Muslim, hence the percentage of each religion in any sample would depend heavily on initial choice of region.

${ }^{12} \mathrm{NER}$ is the proportion of the school aged population who are in school. In this case the NER refers to the proportion of the school aged population in the sample who are in school.

${ }^{13}$ URT (1995b) BEST.

${ }^{14}$ The TADREG (1993) report also raises the possibility that the higher sample enrolment may be an overestimate due to a possible tendency for heads to conceal non enrolment of those children of school-age due to fear of legal consequences, although considers this explanation unlikely.
} 
HRD Survey in 1993/94 found an average age of enrolment of 9.0 years for girls and 9.7 years for boys (World Bank 1995). Parents interviewed within this study frequently commented that enrolment should be postponed until the age of eight or nine since they consider seven year olds as too young and immature to attend school.

Table 3: Proportion of Offspring and Parents that have Never Enrolled in School

\begin{tabular}{|c|c|c|c|c|c|}
\hline Age group & Male & Female & $\begin{array}{l}\text { Household } \\
\text { head if male }\end{array}$ & $\begin{array}{c}\text { Household } \\
\text { head if } \\
\text { female }\end{array}$ & $\begin{array}{l}\text { Spouse if } \\
\text { household } \\
\text { head male }\end{array}$ \\
\hline $7-10$ & 32.9 & 22.1 & 16.1 & 19.4 & 33.3 \\
\hline $11-15$ & 4.5 & 5.1 & 22.2 & 25.3 & 38.0 \\
\hline $16-20$ & 2.3 & 3.2 & 21.6 & 30.2 & 40.5 \\
\hline $21-25$ & 2.2 & 3.3 & 26.6 & 41.9 & 47.0 \\
\hline $26-30$ & 7.2 & 5.5 & 33.1 & 55.1 & 56.2 \\
\hline $31-35$ & 11.1 & 15.2 & 35.2 & 63.2 & 55.6 \\
\hline $36-40$ & 12.5 & 10.5 & 44.3 & 47.8 & 60.4 \\
\hline $41-60$ & 25.8 & 36.7 & 51.9 & 28.6 & 74.1 \\
\hline Average & 8.3 & 7.3 & 26.2 & 38.5 & 45.2 \\
\hline Sample size & 1452 & 1457 & 2470 & 439 & 2470 \\
\hline
\end{tabular}

If the low school attendance in the first age group is caused by late rather than non enrolment then the degree of non enrolment at primary school in the sample is relatively small, particularly given the crisis within the primary education sector portrayed in the main report (see TADREG 1993). This may be linked with the legal obligation to enrol children in school and possibly fairly tight implementation of this legislation within sample villages. Although attendance is similarly compulsory, it is likely to be more difficult to prove absenteeism and hence to punish parents. This may suggest that many parents enrol children for fear of being penalised but withdraw pupils as soon as possible, in other words 'many children are registered but only a few study' (TADREG 1993:16). The higher percentage of offspring without any education in the older age groups and in the older adult age groups, particularly females, reflects the trends in education supply discussed above. Table 4 shows the number of offspring in each age group that fall into each category, and gives a brief indication of the supply conditions when each group was facing critical points in time. 
Table 4: Supply conditions for each age group

\begin{tabular}{|c|c|c|c|}
\hline $\begin{array}{l}\text { Age } \\
\text { group }\end{array}$ & $\begin{array}{l}\text { No. of } \\
\text { males } \\
\text { in the } \\
\text { sample }\end{array}$ & $\begin{array}{l}\text { No. of } \\
\text { females } \\
\text { in the } \\
\text { sample }\end{array}$ & Education supply conditions \\
\hline $7-10$ & 152 & 140 & $\begin{array}{l}\text { Reached the age of } 7 \text { from } 1988 \text { to } 1992 \text {, during the time when } \\
\text { education standards were low. However, many of this group } \\
\text { may not yet have enrolled in school and may do so at an older } \\
\text { age. }\end{array}$ \\
\hline $11-15$ & 290 & 257 & $\begin{array}{l}\text { Reached the age of } 7 \text { from } 1983 \text { to } 1987 \text {, during the time when } \\
\text { education standards were declining and many families faced } \\
\text { severe economic problems. }\end{array}$ \\
\hline $16-20$ & 346 & 379 & $\begin{array}{l}\text { Reached the age of } 7 \text { from } 1979 \text { to } 1982 \text {, when overall primary } \\
\text { enrolments were high, although quality problems were } \\
\text { beginning to be felt. They would have reached Standard VII in } \\
1986 \text { to } 1989 \text { when the rate of expansion of secondary } \\
\text { education was beginning to increase and the costs of secondary } \\
\text { education were rising. }\end{array}$ \\
\hline $21-25$ & 278 & 270 & $\begin{array}{l}\text { Reached the age of } 7 \text { in } 1974 \text { to } 1978 \text { at the peak of the UPE } \\
\text { drive hence explaining the high enrolments within this group. } \\
\text { They completed primary school in 1981-1985, when the } \\
\text { transition rate to secondary school had declined steeply. }\end{array}$ \\
\hline $26-30$ & 208 & 199 & $\begin{array}{l}\text { Reached the age of } 7 \text { in } 1969 \text { to } 1973 \text {, although prior to UPE } \\
\text { drive many may have enrolled at school at a later age. It is } \\
\text { interesting that within this group a reversion of the gender } \\
\text { difference occurs i.e. more girls have attended school than } \\
\text { boys, compared with a fairly prominent gender bias against } \\
\text { girls amongst the older groups and amongst the parents. }\end{array}$ \\
\hline $31-35$ & 108 & 92 & $\begin{array}{l}\text { Reached the age of } 7 \text { in } 1964 \text { to } 1968 \text {, post independence but at } \\
\text { a time when the stress for education remained on gradual } \\
\text { primary expansion and immediate secondary level expansion. }\end{array}$ \\
\hline $31-40$ & 72 & 57 & $\begin{array}{l}\text { Reached school-age from } 1959 \text { to } 1963 \text { around the time of } \\
\text { independence, when education policies were yet to be } \\
\text { formulated and opportunities remained limited and regionally } \\
\text { differentiated. Christian missionaries played an important role. }\end{array}$ \\
\hline $41-56$ & 31 & 30 & $\begin{array}{l}\text { Those in the older age group and most of the parents would } \\
\text { have began school (pre 1958) when education opportunities for } \\
\text { the majority were limited. Although the proportion attending } \\
\text { secondary was very small, for those few reaching as far as } \\
\text { primary completion the progression rate to secondary was } \\
\text { relatively high. }\end{array}$ \\
\hline
\end{tabular}


Figure 1 shows that the majority of those still in primary school are within the 11-15 group, although some are in the 16-20 age group (17 per cent of the males in this group and 11.7 per cent of the females).

\section{Figure 1: Educational Attainments by age group}

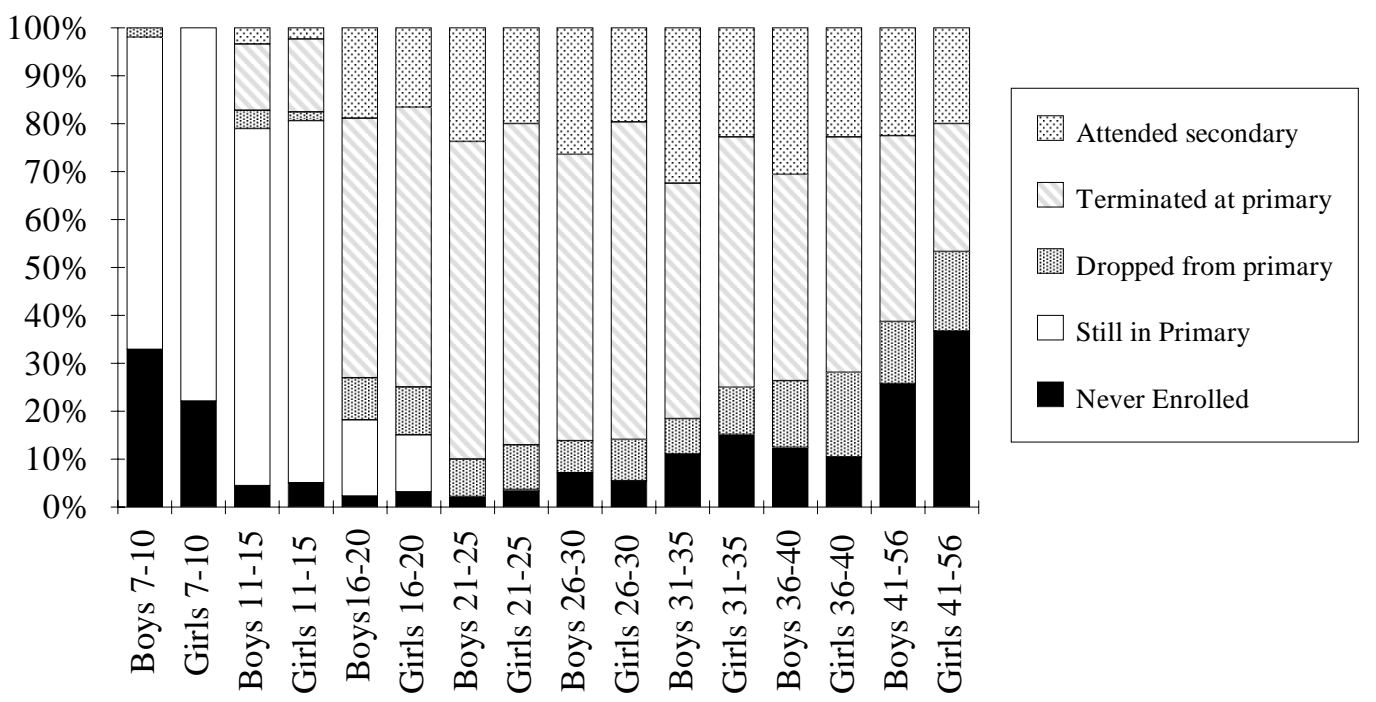

The percentage of those who dropped out of primary school in each age group remains fairly similar, rising slightly for the older groups. The proportion in each age group that attends or has attended secondary school remains fairly constant, with a fairly consistent gap between male and female enrolment. ${ }^{15}$ However, when expressed as a percentage of only those who have completed primary school (shown in Table 5), the higher attendance in older groups, as discussed earlier, is evident. Similarly the lower representation of women at secondary level, out of those who complete primary school, is notable in each age group.

Table 5: Proportion Attending Secondary School of those who have Completed Primary School

\begin{tabular}{l|c|c}
\hline Age group & Male & Female \\
\hline $11-15$ & 20.0 & 13.3 \\
$16-20$ & 25.6 & 22.8 \\
$21-25$ & 26.4 & 23.0 \\
$26-30$ & 30.7 & 22.8 \\
$31-35$ & 39.8 & 30.4 \\
$36-40$ & 41.5 & 31.7 \\
$41-60$ & 36.8 & 42.9 \\
Total & 29.1 & 24.0 \\
Sample size & 894 & 859 \\
\hline
\end{tabular}

\footnotetext{
${ }^{15}$ It is likely that this sample over represents secondary attendees due to the fact that villages included in this sample historically have had secondary education supply.
} 
The lower progression of Standard VII girls into secondary school has been attributed to girls' weaker performance at primary level in situations of constrained secondary places. It has been argued that the fact that private schools have a higher proportion of girls than public schools implies that parental attitudes are quite healthy and they choose to invest in girls education voluntarily (Omari 1995: 19). However, the percentage of Standard VII enrolees who are not allocated places at public school and who then attend private school is higher for boys than girls, implying that household demand still has a differing role in boys' and girls' education opportunities. ${ }^{16}$ At the time of transition between primary and secondary school girls face additional problems arising out of puberty, expectations of marriage, risk of and actual pregnancy.

\subsection{Problems Arising Within the Data Set}

There are some generic problems common to the use of cross section household surveys to investigate the education attainments of offspring. Firstly, the information collected on the household at the time of the survey is then used to explain education decisions which have been made in a previous time period when the characteristics of the household may have been different. This is likely to be particularly problematic when considering older children. However, many of the independent variables used in this case (e.g. ethnicity, religion, formal education of parents) either could not or are unlikely to have altered over time. Parental occupation and marital status may have altered over time, and through migration so may the households' village location, which is used as a control dummy. To some extent this remains an unresolvable problem and is explored in terms of ensuring the regression results are robust to different age sub-samples. Secondly there is a bias towards larger families. Since each randomly sampled household provides information on all children, analysis of the individual child results in a non random sample which has a bias towards children from large families. ${ }^{17}$

Not all household and community characteristics which influence education decisions are included within the data set used here, raising the possibility of omitted-variable bias in the regression analysis. Direct information on household income, expenditures and socio-economic status are not available within this data set, yet the status of household wealth and current income would have a strong determining influence on education decisions. However, such data are likely to be extremely unreliable, and highly correlated with other independent variables. Using current household income would make the problems of changing household characteristics, discussed above, even more severe. Within the regressions the occupation grouping and to some degree

${ }^{16}$ Calculated from data from URT 1995 b.

${ }^{17}$ In this sample only information on the eldest seven children of the household head were taken. Therefore the bias towards large families is slightly reduced. 
parental education levels are used to proxy for household socio-economic status. The occupation groups are relatively good at picking up the better off sections within the sample, however, the broad farming category, which comprises over three quarters of the sample, is not a good distinguisher of household income levels. "There is a world of difference between largely illiterate farmers in an impoverished village in Dodoma Rural or Iramba District, and the inhabitants of a more prosperous and literate village in Mbeya or Moshi Rural" (TADREG 1993:26). However, consideration of the village level information found that "inequities of income and land ownership were generally insubstantial within village sub-samples", which suggests that income differences between farmers may be partly controlled for by the village dummies. Village dummies, occupation groups and parental education together are likely to be good proxies for household income levels, however, the interpretation of the impact of these variables is likely to be difficult.

The village dummies are also used to control for local supply factors, such as the availability of places and quality of schooling in the area. Supply factors are likely to have been particularly crucial prior to the expansion of education places after independence and the UPE drive. Access to secondary level education has been found to have a positive impact on primary education demand (Mason and Khandker 1996). However, evidence from these mainly Christian villages suggests a long history of relatively high education supply and only minimal increases in supply following the UPE drive (TADREG 1993). The village dummies also control for legal strength in a village and perceived local penalties of contravening the compulsory enrolment and attendance legislation.

Complete information on the direct and opportunity costs to the households is also missing, which would include school contributions and costs of uniforms in the location and the proximity to the local primary school. For each individual child their ability level is also likely to influence the willingness of parents to undergo investment in their education at primary and secondary level. Ability level of the child will be influential in the determination of attendance at secondary school, particularly prior to the expansion of private secondary schools. ${ }^{18}$

Despite problems with the data set it remains extremely rich. The inevitable absence of full information regarding the costs and benefits to the households of childrens' education will mean that the effect of a variable could be proxying for other unrecorded characteristics and therefore there may be some ambiguity regarding the interpretation of some of the significant relationships unearthed through the regression analysis.

\footnotetext{
${ }^{18} \mathrm{At}$ primary level the omitting of an ability variable will result in overlooking the children of school-age excluded from schooling due to physical or mental handicaps. According to the 1988 census these children number 105,800 (approximately $3 \%$ of the school-age population) and almost all of them are excluded from the education system.
} 


\section{RESULTS}

Although a pooled regression was run for each of the three regressions the results reported here are the male and female marginal and impact effects recoverable from the pooled regression, and the effects of the variables that do not have gender slope dummies. ${ }^{19}$

\subsection{Primary School Enrolment}

The first logit was run on all of the sample, of 11 years of age and above, using as a dependent variable whether or not an individual had ever attended primary school. The results are reported in Table 6. The exclusion of those under 11 was to ensure that the regression was explaining non enrolment and to avoid the problem of censoring within the sample. The vast majority of the sample had attended primary school, or currently attended school, with only 6.5 per cent of the sample never having attended primary school. ${ }^{20}$

The probability of enrolment at primary school was found to be significantly and positively associated with age for girls and boys within the sample, implying that younger individuals are less likely to enrol. This may be picking up changing parental attitudes on the quality of schooling and its returns.

\footnotetext{
${ }^{19}$ Marginal and impact effects are reported for all variables except for the village and tribal dummies. The significance of any of the differences between the male and female impact and marginal effects are not reported here but in the appendix. The test of the difference between the male and female coefficients is equivalent to looking at the significance of the gender slope dummy for the variable in question.

${ }^{20}$ This regression excludes some of the independent variables (some of the tribal and some district dummies and secondary education of heads and spouses) because they had a collinear relationship with the dependent variable on one side. For example, if either the spouse or the household head had secondary education all of their children would have enrolled in primary school. Because of this relationship it was not possible to estimate the regression with these variables included.
} 
Table 6: Selected Impact and Marginal Effects from the Logit Regression on Primary

\section{School Attendance}

\begin{tabular}{|c|c|c|c|}
\hline Variable & $\begin{array}{l}\text { Marginal effects/ } \\
\text { Impact effects }\end{array}$ & $\begin{array}{c}\text { Marginal effects/ } \\
\text { Impact effects for boys }\end{array}$ & $\begin{array}{c}\text { Marginal effects/ } \\
\text { Impact effect for girls }\end{array}$ \\
\hline AGEHD & 0.0004 & & \\
\hline HEADSEX & 0.0502 & & \\
\hline MUSLIM & & 0.050 & 0.008 \\
\hline PAGAN & & -0.054 & $-0.077 *$ \\
\hline OCCHD2 & & $-0.112 * *$ & $-0.078^{*}$ \\
\hline OCCHD3 & & 0.047 & $0.125^{* *}$ \\
\hline OCCHD4 & & 0.011 & 0.059 \\
\hline OCCHD5 & & -0.081 & 0.007 \\
\hline POSKID & & -0.003 & $-0.006 * *$ \\
\hline NOCDHH & $0.006 * * *$ & & \\
\hline TYPMRR & & 0.015 & $-0.088 * *$ \\
\hline MARIT2 & & 0.099 & -0.041 \\
\hline MARIT3 & & 0.017 & -0.0004 \\
\hline MARIT4 & & 0.080 & 0.061 \\
\hline HDPRIM & & $0.114 * * *$ & $0.049 *$ \\
\hline SPOPRIM & & 0.038 & $0.111 * * *$ \\
\hline ILLIT & $-0.064 * *$ & & \\
\hline AGEKID & $0.003 * * *$ & & \\
\hline sample size & 2617 & & \\
\hline \multicolumn{4}{|c|}{ Test Statistics } \\
\hline \multicolumn{2}{|c|}{ Log of likelihood function } & -394 & \\
\hline \multicolumn{2}{|c|}{ Likelihood ratio test statistic } & $401 * * *$ & \\
\hline \multicolumn{2}{|c|}{ McFadden's Pseudo Rsquared } & 0.41 & \\
\hline
\end{tabular}

The regression results predicting the probability of ever having attended school show a close relationship between household characteristics and the probability of enrolment. Division of labour within the household implies that mother's and daughter's household labour time is substitutable. Changes in mothers opportunities outside the household will result in an income and substitution effect with regards to her daughters allocation of time to household chores. The increased income to the family will imply that more resources are available and the total amount of labour time needed for household reproduction may fall (through, for example, the use of processed foods). The income effect will have a positive effect on girls schooling chances through a general increase in resources available for schooling as well as a fall in the demand for her labour time within the household. The substitution effect will cause the daughters to take on more of the household chores in replace of the mother implying that they will have less time to go to school. It is possible that either of these effects will dominate. 
Girls from households with heads who are involved in some form of trade, are 12.5 per cent more likely to have enrolled in school compared with those in farming households. This may be proxying for an income effect (with the possible interpretation that girls education is more income elastic). If this is the case then it is initially surprising that the impact of households in paid employment is not significant. However, wage levels, particularly within the government sector have been very low and indications suggest that trading families may have higher incomes (URT 1993). Alternatively, there may be less need for girls labour relative to boys labour in trading households compared to the relative labour demands in farming households. Another possibility may be that returns to education for girls (e.g. basic numeracy) are perceived to be more useful in trading households owing to the possibility of teenage girls helping with the business.

Individuals from households which follow Pagan beliefs have a lower probability of ever having attended school compared to Christian households with the probability of attendance being reduced by 7.7 per cent for girls. Cultural preferences in terms of attitudes towards education, income effects, differences in household production systems or supply effects are likely to be underlying this result. Groups which still practice traditional beliefs may have been more likely to be nomadic hence creating problems in terms of access to education. Interpretation of this result is tentative because the surveyed areas are predominantly Christian and therefore other groups (i.e. Pagan and Muslim groups) in the sample are unlikely to be representative.

The negative effect of belonging to a cattle herding household for boys and girls compared to belonging to a farming household (lowering the probability of enrolment by 11.2 per cent for boys and 7.8 per cent for girls) is probably due to the higher opportunity costs of children's labour in such households. This is particularly true for boys who are often responsible for grazing the cattle. In addition, the connection with cattle rearing may also be picking up supply problems of bringing education to nomadic groups.

As would be expected the education level of parents improves the probability of school enrolment. Basic literacy of the household head improves both girls and boys chances equally, with offspring from illiterate households having a six per cent lower probability of enrolling. This impact is in addition to the positive effect of parents having primary education, and suggests a positive role for adult literacy programmes. The impact of head's primary education suggests that the head's education has a much greater influence on male children (primary education increasing boys chances of enrolment by 11.4 per cent and girls by 4.9 per cent) whereas the spouse's primary education has a greater influence on the female children, increasing girls enrolment chances by 11.1 per cent but having an insignificant effect on boys enrolment. This relationship has also been found by Mason and Khandker (1996), Tansel (1993) and Appleton, Collier and Horsnell (1990). The greater influence of mothers on female children may be due to mothers 
having a relatively stronger preference for their daughters education and their education affording them either increased household decision-making power or increased economic status. Belonging to a polygamous household has a negative effect on the probability of girls (although not boys) enrolling, lowering it by 8.8 per cent, which may result from a lower status of females within such households and their unequal claim on household resources compared to boys. Interestingly, belonging to a female-headed household is positively associated with enrolment, for boys and girls, although the effect is not significant in this regression.

In addition to the characteristics of the parents, how many siblings the child has and their birth order is thought to influence a child's potential access to schooling. The number of children within a household is likely to effect the level of resources available to each individual child, negatively through the need to share resources more widely and positively through the potential of older children to provide support for younger children. Children within a household may also share household work loads, with an increased number of children potentially reducing each individual's work load. However, given a situation of a rigidly defined gender division of labour the child's sex and that of their siblings is likely to affect the impact of additional children on their educational attainments (Parish and Wills 1993).

Birth order within the family is also likely to be important, as well as the relative age of other siblings. Where children, mainly girls, take on the responsibility for caring for younger siblings, being born early may increase the opportunity cost of schooling. Where education is treated as an investment good, once some children in the family have education and secured some future income for the parents this may alter household preferences for further educated children. Additionally, the experience of one child attending school may effect the probability of younger children attending school, either positively (through increasing knowledge about school life, and awareness that girls may perform successfully in academic subjects) or negatively (where bad experiences have occurred, e.g. a girl is expelled due to pregnancy and hence the parents feel investment is wasted). ${ }^{21}$

In order to explore the effect of birth order and siblings, a variety of specifications were used including ones which separated siblings by gender and whether they were older or younger. The use of birth order and the total number of children in the household proved to be a preferable specification, although it remains unclear exactly how siblings influence education decisions. What is clear is that boys and girls appear to be affected by birth order in a different manner, supporting the notion that boys and girls have differential access to household resources and/or experience a gendered division of household labour.

\footnotetext{
${ }^{21}$ Current policy in Tanzania allows expulsion of school girls due to pregnancy. The policy remains under review but was not changed in the 1995 Education Act Amendment
} 
The coefficient on birth order in this regression does not have an effect on boys enrolment, but the lower the birth order for girls the worse their chances of enrolling, with a marginal effect of 0.6 per cent. This may be indicating that younger girls come low in the order of allocating resources or that household preferences towards education change. The positive and significant effect of the number of children in the household, implies that both boys' and girls' chances of schooling improves where there are more children in the household. The marginal effect is 0.6 per cent for boys and girls. This positive effect could be due to the opportunities for other children to share the household work load, lowering the effective opportunity cost of each child's schooling or that children from large families benefit from remittances from older siblings.

In general, although the regression is significant the impacts are fairly small. For the majority of offspring in each category the probability of at least initially enrolling in school is high within this sample. One of the strongest effects is parental education. Although there is a possibility that this is proxying for an income effect, other comparable studies have found low income elasticity's of demand for education in Tanzania (Collier et al 1990: 130, Mason and Khandker 1996).

\subsection{Completion of Primary School}

The second logit regression considered whether children completed primary schooling conditional on enrolling in primary school. Children of 15 years and over were considered although this was older than the official end of primary school due to the potential for late enrolment to result in 1314 year olds still not completing schooling.

It may be expected that completion of primary education may be more closely associated with household characteristics than initial enrolment due to the fact that initial enrolment is compulsory and completion is not. Overall 10 per cent of the sample who had attended primary school dropped out before completion. 
Table 7: Selected Marginal and Impact Effects for the Logit Regression on Primary School Completion

\begin{tabular}{lccc}
\hline Variable & $\begin{array}{c}\text { Marginal Effects/ } \\
\text { Impact effects }\end{array}$ & $\begin{array}{c}\text { Marginal Effects/ } \\
\text { Impact effects for boys }\end{array}$ & $\begin{array}{c}\text { Marginal effects/ } \\
\text { Impact effects for girls }\end{array}$ \\
\hline AGEHD & $0.002^{*}$ & 0.0004 \\
HEADSEX & $0.064^{* *}$ & 0.028 \\
MUSLIM & $-0.068^{* *}$ & 0.021 \\
PAGAN & 0.016 & -0.003 \\
OCCHD2 & 0.014 & -0.021 \\
OCCHD3 & 0.043 & -0.045 \\
OCCHD4 & -0.002 & 0.057 \\
OCCHD5 & -0.008 & 0.048 \\
POSKID & $-0.008^{*}$ & $0.034^{*}$ \\
NOCDHH & & 0.030 \\
TYPMRR & 0.004 & -0.041 \\
MARIT2 & $-0.074^{*}$ & -0.015 \\
MARIT3 & -0.064 & -0.025 \\
MARIT4 & -0.006 & $0.067^{* * *}$ \\
HDPRIM & $0.012^{*}$ & $0.040^{*}$ & 0.051 \\
HDSEC & & -0.033 & $0.047^{* *}$ \\
SPOPRIM & & $0.061^{* * *}$ & 0.028 \\
SPOSEC & & 0.016 & \\
ILLIT & & & \\
AGEKID & & & \\
Sample size & & & \\
Test Statistics & 1925 & & \\
Log of likelihood function & & & \\
Likelihood ratio test statistic & & \\
McFadden's Pseudo Rsquared & & \\
& & & \\
\hline
\end{tabular}

*- significant at the $10 \%$ level

**- significant at the 5\% level

***- significant at the $1 \%$ level

The regression for primary school completion does not have as large an explanatory power as that for initial enrolment, the McFadden's Pseudo R squared is 0.27 compared with 0.41 in the first model. This suggests that omitted variables are more of a problem here and that the variables included in the regression are not as important in explaining completion compared to initial enrolments. Qualitative information on the causes of drop-out from school in two districts in Tanzania in 1995 suggests that although drop-out is closely related to poverty, many social factors also play a strong role with the pupils themselves sometimes taking actions which result in dropout independently of their families' wishes (IDS and MOEC 1996). If this is the case then we would not necessarily expect household characteristics to have such a strong influence on the probability of dropping out of school. 
In terms of completion of primary school, age was found to reduce the probability of completion for both boys and girls. Constrained education access prior to the UPE drive is likely to explain this result since completion is treated as completing at least 7 years of schooling and therefore incomplete primary schools and exam barriers prior to 1970 will have increased the percentage of non completers in the older age groups. Recent evidence suggests a rise in the drop-out rate in the late 1980s and early 1990s (World Bank 1995, IDS and MOEC 1996) however, this was not evidenced by this data set. ${ }^{22}$

The effect of the socio-economic status of the household on the probability of primary school completion is not picked up strongly within this regression. The occupation of the household head does not have a significant effect on the probability of completion. However, education of the head and spouse does increase the probability of completion. Basic literacy of the household head does not improve offspring completion chances, but heads having attended primary school does, with the effect being similar for boys and girls (increasing girls chances by 6.7 per cent and boys by 4 per cent). However, children from households with heads with additional secondary education do not further improve their chances of completion. A similar relationship occurs with spouses education, with primary education increasing the probability of completion (6.1 per cent for boys and 4.7 per cent for girls), but secondary education having no additional effect. The theory that spouses education has a greater impact on girls' education than on boys and visa versa for household heads appears to be contradicted here, but it should be noted that the differences in the effects on boys and girls are not statistically significant.

Significant gender differences do, however, appear in the impact of religion, household heads' gender, marital status and age. Muslim boys are 6.8 per cent less likely to complete school than Christian boys, although no difference is picked up for girls or for those from Pagan households. The latter may be indicating that the earlier result (a negative effect on enrolment in Pagan households) was a supply rather than a demand problem. If a child from a Pagan household has initial access to school then they are as likely to complete as a child from a Christian household. It is unclear why the negative effect of being Muslim is only significant on boys completion; the impact of Islam on boys completion could be being caused by boys possible attendance at Madrasa classes constraining their ability to fully attend formal school or it could be proxying for a gender sensitive income effect. Alternatively, when the results are interpreted in a different way, they may be suggesting that Christian boys stand more chance of completion which may be indicating a gender bias within Christian households. It may be the case that the Muslim households in predominantly Christian areas have different characteristics to other Muslim households hence little generalisation can be made of this result. However, it is interesting in that

${ }^{22}$ Variations in the model specifications, including non linear specifications of the age variable and a slope dummy for the under 21 group did not pick up any significant effect of an increase in drop out rates in the younger groups. 
it challenges the common interpretation that Muslim girls suffer an additional disadvantage in terms of education access.

The negative impact of coming from a divorced household for boys and the positive impact of older households heads, may be indicating a need for discipline and stability for boys in order to ensure their completion. The first regression tentatively suggested that female-headed households appear to put a higher priority on their children's education, and one possible reason for this effect showing on boys' completion chances and not on girls' could be that the benefit to girls of being in a female-headed household where education is a greater priority in terms of income allocation may be slightly offset by the need for female-headed households to use daughter's labour as a substitute to their own. This result, however, needs to be interpreted in the context of the marriage status of the family. For example, if the boy comes from a divorced household there is a significant negative effect on completion chances and more female-headed households are divorced which will reduce the positive impact of coming from a female-headed household for boys.

The positive effect on the number of children in the household, similarly to the enrolment regression, may be indicating the benefits of having more elder children in the family who are able to provide additional financial support. The position of the child, although only significant at the 10 per cent level, slightly reduces the probability of boys completing ( 0.8 per cent) and raises the probability of girls completing (3.4 per cent). The effect on girls suggests that younger girls stand more chance of completing, possibly due to having less child care responsibilities and hence lower opportunity costs of schooling. This result slightly contradicts that found within the enrolment regression and may be suggesting that girls domestic work, has a more detrimental effect on completion than enrolment, possibly due to girls tiredness at school, poor attendance, and consequently lower performance.

\subsection{Attendance at Secondary School}

The logit on secondary school attendance considers the attendance or non-attendance of all those offspring who had completed primary school. Of those who have completed primary school 26.6 per cent go on to secondary school. Again this confirms the greater educational achievements of this sample compared to the national average. 
Table 8: Selected Marginal and Impact Effects from the Logit Regression on Secondary School Attendance Conditional on Completion of Primary School

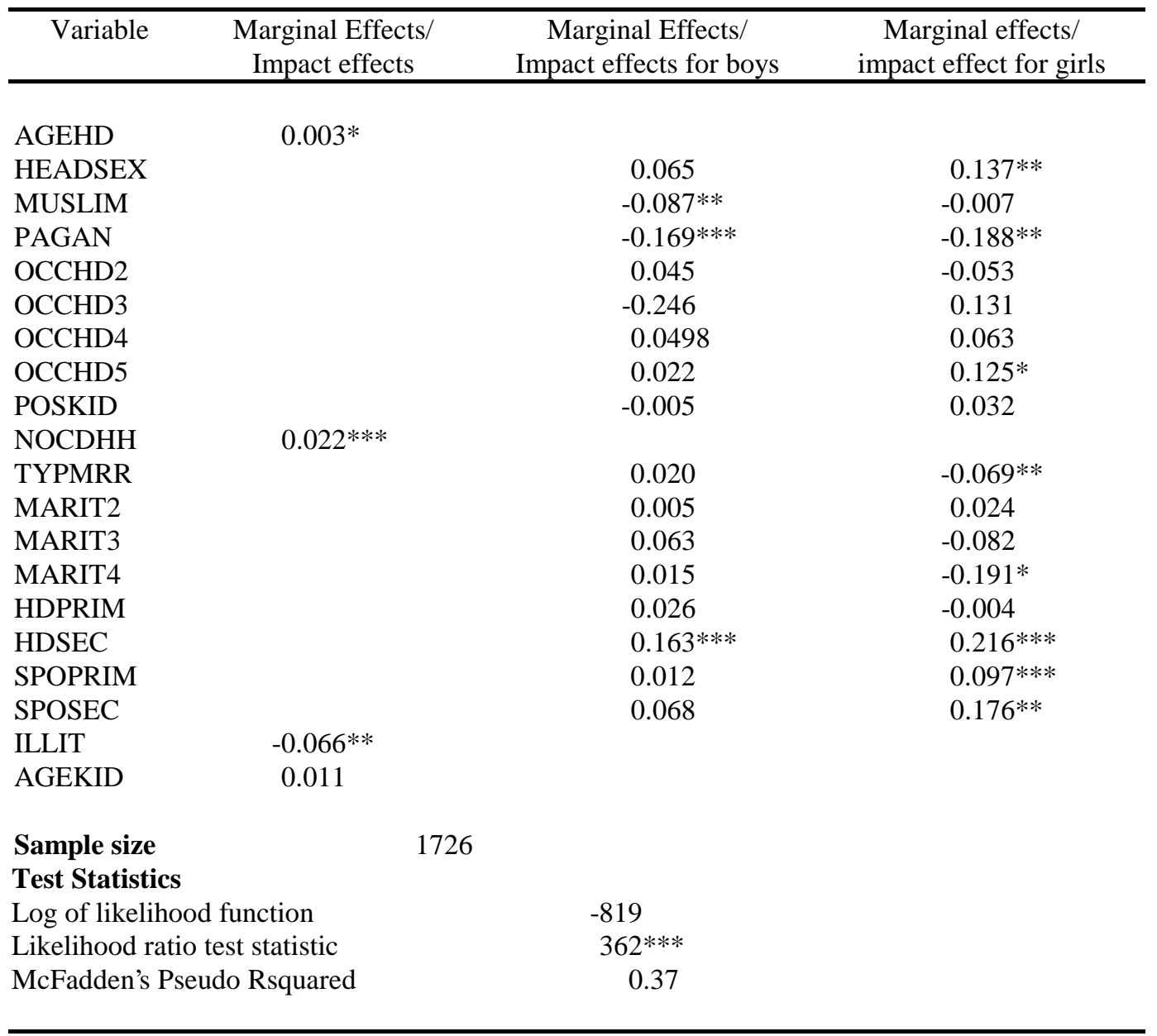

\footnotetext{
*- significant at the $10 \%$ level

$* *$ - significant at the $5 \%$ level

***- significant at the $1 \%$ level
}

The logit for attendance at secondary school, given that individuals have already completed primary school, reveal very strong relationships between household characteristics and secondary school attendance. One of the strongest predictors of attendance at secondary school is whether or not parents have attended secondary school, suggesting the important impact of parental education upon that of their children.

The limited education access facing the older groups within the sample appears to be reversed when considering which individuals attended secondary school, with both older males and older females that have completed primary school being more likely to attend secondary school. Referring back to Figure 1, it should be noted that it is the change in the percentage of Standard VII leavers that graduate to secondary school (caused by disproportionate growth in the primary 
sector) which drives this effect rather than a decline in the overall enrolment rate at secondary level.

As discussed in Section 2 the supply constraints are more binding at the secondary level. Before the 1980 's, when private secondary schools were tightly restricted, secondary school attendance was intended to be determined mainly by meritocratic criteria, determined by success in the Primary School Leaving exam and district male and female quotas. It was thought that under this theoretically equitable scenario secondary school access would have been relatively independent of households socio-economic status. Previous empirical research (Malekela 1986, Knight and Sabot 1990) however, found close relationships between household characteristics and secondary school attendance in Tanzania. Higher socio-economic groups are over represented in those gaining access to secondary school implying that government resources were not being targeted at the most needy. Between 1980 and 1992 the percentage of secondary pupils enrolling into the private secondary school sector rose from 44 to 60 percent. While in some community schools access is still partly dependent on examination performance, for the vast majority household socio-economic status determines access. The involvement of NGOs and religious groups in establishing secondary schools has raised fears that access to secondary education has become increasingly inequitable along religious, gender, ethnic, and geographical lines. (Galabawa 1994). However, the general expansion is thought to have increased the access by lower socio-economic groups to secondary education, and hence has reduced inequities. Indeed, many non-government schools are of poorer quality and serve in one way lower socio-economic groups.

Religious inequities are strong, with Muslim boys being particularly disadvantaged. Boys belonging to a Muslim household relative to a Christian household have an 8.7 per cent lower probability of attending secondary school. Belonging to a Pagan household lowers the probability of attending secondary school for both boys and girls (by 16.9 per cent and 18.8 per cent respectively), although once again this result involves small cell sizes. The negative effect of being Muslim is a likely result given that Muslims have traditionally been perceived as having experienced unequal access to secondary schooling, and the fact that Christian denomination secondary schools outnumber Muslim schools by 10:1 (Galabawa 1994). The lack of a relationship for girls is again interesting. However, a strong negative relationship for girls belonging to polygamous households is found. This may imply that the common view of unequal access for Muslim girls has more to do with cultural arrangements, persistence of traditional values, power and resource allocation decisions than religious beliefs.

The important role mothers have on girls' education is clearly shown in this regression. Girls from female-headed households increase their probability of going to secondary by 13.7 per cent, whereas the gender of the household head does not have a significant effect on boys. This 
suggests greater prioritising of education expenditures by female heads, despite the fact that they are likely to be of lower socio-economic status. This result parallels that found by the Demographic Health Survey in 1991/1992 that "married mothers whose husband lives in the household are more constrained in their allocation of resources to health care utilisation for the welfare of their children than single mothers or mothers whose husbands are living outside the household" (Katapa and Astore 1993 cited in Kaijage and Tibaijuka 1996). These results appear to be supporting some kind of 'co-operative conflict' model of allocating household resources, whereby men and women have different demands for education for their daughters and sons, due to economic reasons and/or differing preferences and responsibilities and their ability to assert control over resources in the household. Where women have greater control over resources, either due to higher education levels, or increased income contributions to the household, studies have frequently found increased consumption of food and child welfare goods (Tinker 1987, Hoddinott and Haddad 1991).

Additionally, spouses' primary education increases the probability of girls going to secondary school by 9.7 per cent and spouses secondary education by a further 17.6 per cent (i.e. 27.3 per cent more likely to go in households with spouses with secondary education compared to households with spouses with no education), but again there is no effect for boys. Why the mother's education position should come out so strongly in favour of girls at this level, when in the previous regression it appeared to be supportive but more gender neutral is interesting. One possible explanation could be that, given the greater costs involved in secondary education, girls' unequal access to resources comes into play more at this level, and hence mothers' control over household resources and their prioritisation of education investment has a critical role in girls' secondary school access.

Secondary education of the household head is positively and strongly related to both boys and girls access to secondary school (21.6 per cent for girls and 16.3 per cent for boys although the difference between them is statistically insignificant). Although no effect is found for whether the head has attended primary school, basic literacy does improve offspring's chances of attending secondary school with boys and girls coming from households with illiterate heads having a 6.6 per cent smaller chance of attending secondary school.

The slightly greater relevance of occupation and marriage status on girls, may be implying that girls access is determined more strongly by household socio-economic status than boys, a result which has been found in other research (Sumra 1993, Appleton et al 1990, Malekela 1986). Girls from single parent households are 19.1 per cent less likely to attend secondary school, possibly due to the need for their labour in daily reproduction of the household. This effect is likely to reduce the positive impact for a girl of being in a female-headed household. 
In line with the other regressions the number of children within the household has a positive effect on education attainments, for both boys and girls. However, the position of the child is insignificant in this case.

The probability of secondary school attendance within this sample is therefore highly effected by the household characteristics for which we have data. For example, the probability of attendance at secondary school for a girl from a Pagan, polygamous, farming household where the head and first spouse have no education is 14.8 per cent (with all other independent variables taken at their mean). Whereas the probability of attendance of a girl from a Christian, monogamous household where both parents have secondary education and the father is a trader is 80 per cent. These figures compare closely to those found by Knight and Sabot (1990) that parental secondary education has a strong influence on lower secondary completion.

\section{CONCLUSION}

These three regressions clearly reflect substantial intra household differences, between the way in which household characteristics affect outcomes for boys and girls, and how male and female influence over resource decisions differently affect outcomes.

The regressions reflect a different demand for education within female-headed households compared to male-headed households, boys being significantly more likely to complete primary school and girls being far more likely to attend secondary school if they are from female-headed households.

These regressions give weight to the notion that mothers' education has more influence on girls enrolment decisions whereas fathers education' has more influence on sons enrolment. Critically, married mothers' primary education can increase the probability of girls enrolling in secondary school by 9.7 per cent and their secondary schooling by a further 17.6 per cent, while having no significant effect on boys. The different effects of having married mothers for girls and boys may be an income effect (households with educated spouses being relatively better off), hence implying girls' greater vulnerability to household income, and consequently cost sharing measures. Alternatively, the result could be caused by mothers having a greater preference for educated daughters and, as held within a 'cooperative conflict' model, education allowing them greater voice within household decision-making. The important role of mothers in determining girls' education outcomes, and the positive role of spouse's education suggests that investment in girls' education would have benefits in terms of future education decisions. Therefore, gender segregated policies in the short term would ultimately become redundant as women are elevated to 
a position where they can better address inequity of resource allocations and labour responsibilities within the household.

In general, the three regressions imply that educated households are able to ensure their children receive relatively high levels of education although the means through which this is achieved are uncertain (e.g. income effects, assistance with school work etc.). This lack of intergenerational mobility is less striking in terms of primary education. The results on secondary attendance imply that to improve intergenerational mobility there is a need for effective targeting of support to individuals, particularly girls, from households with low levels of human capital. 


\section{APPENDIX}

All variables that are prefixed with a $\mathbf{G}$ are the gender slope dummies (i.e. 1 if female, 0 otherwise.

A1: Descriptive Statistics for the Enrolment Regression

\begin{tabular}{|c|c|c|c|c|c|c|}
\hline & MEAN & STD DEV & MIN & MAX & SUM & VARIANCE \\
\hline $\mathrm{C}$ & 1.000 & 0.000 & 1.000 & 1.000 & 2617.000 & 0.000 \\
\hline VILL & 0.085 & 0.279 & 0.000 & 1.000 & 223.000 & 0.078 \\
\hline VILL3 & 0.070 & 0.254 & 0.000 & 1.000 & 182.000 & 0.065 \\
\hline GVILL3 & 0.035 & 0.183 & 0.000 & 1.000 & 91.000 & 0.034 \\
\hline VILL5 & 0.048 & 0.213 & 0.000 & 1.000 & 125.000 & 0.046 \\
\hline VILL7 & 0.087 & 0.282 & 0.000 & 1.000 & 228.000 & 0.080 \\
\hline VILL8 & 0.041 & 0.199 & 0.000 & 1.000 & 108.000 & 0.040 \\
\hline GVILL8 & 0.023 & 0.151 & 0.000 & 1.000 & 61.000 & 0.023 \\
\hline VILL9 & 0.088 & 0.283 & 0.000 & 1.000 & 230.000 & 0.080 \\
\hline VILL10 & 0.081 & 0.272 & 0.000 & 1.000 & 211.000 & 0.074 \\
\hline GVILL10 & 0.039 & 0.194 & 0.000 & 1.000 & 102.000 & 0.037 \\
\hline VILL11 & 0.069 & 0.254 & 0.000 & 1.000 & 181.000 & 0.064 \\
\hline VILL12 & 0.042 & 0.202 & 0.000 & 1.000 & 111.000 & 0.041 \\
\hline GVILL12 & 0.022 & 0.147 & 0.000 & 1.000 & 58.000 & 0.022 \\
\hline VILL13 & 0.019 & 0.138 & 0.000 & 1.000 & 51.000 & 0.019 \\
\hline VILL14 & 0.058 & 0.234 & 0.000 & 1.000 & 152.000 & 0.055 \\
\hline GVILL14 & 0.031 & 0.174 & 0.000 & 1.000 & 82.000 & 0.030 \\
\hline VILL15 & 0.058 & 0.235 & 0.000 & 1.000 & 153.000 & 0.055 \\
\hline KIDSEX & 0.491 & 0.500 & 0.000 & 1.000 & 1284.000 & 0.250 \\
\hline AGEHD & 53.360 & 9.058 & 30.000 & 86.000 & 139644.000 & 82.040 \\
\hline HEADSEX & 0.156 & 0.363 & 0.000 & 1.000 & 408.000 & 0.132 \\
\hline ISLAM & 0.157 & 0.364 & 0.000 & 1.000 & 412.000 & 0.133 \\
\hline GISLAM & 0.075 & 0.263 & 0.000 & 1.000 & 195.000 & 0.069 \\
\hline PAGAN & 0.060 & 0.238 & 0.000 & 1.000 & 157.000 & 0.056 \\
\hline GPAGAN & 0.029 & 0.168 & 0.000 & 1.000 & 76.000 & 0.028 \\
\hline OCCHD2 & 0.053 & 0.225 & 0.000 & 1.000 & 140.000 & 0.051 \\
\hline GOCCHD2 & 0.022 & 0.146 & 0.000 & 1.000 & 57.000 & 0.021 \\
\hline OCCHD3 & 0.054 & 0.226 & 0.000 & 1.000 & 141.000 & 0.051 \\
\hline GOCCHD3 & 0.028 & 0.165 & 0.000 & 1.000 & 73.000 & 0.027 \\
\hline OCCHD4 & 0.085 & 0.279 & 0.000 & 1.000 & 223.000 & 0.078 \\
\hline GOCCHD4 & 0.042 & 0.201 & 0.000 & 1.000 & 110.000 & 0.040 \\
\hline OCCHD5 & 0.041 & 0.199 & 0.000 & 1.000 & 108.000 & 0.040 \\
\hline GOCCHD5 & 0.016 & 0.127 & 0.000 & 1.000 & 43.000 & 0.016 \\
\hline POSKID & 3.252 & 1.811 & 1.000 & 7.000 & 8510.000 & 3.281 \\
\hline GPOSKD & 1.609 & 2.069 & 0.000 & 7.000 & 4210.000 & 4.279 \\
\hline PSKDSQR & 13.854 & 13.626 & 1.000 & 49.000 & 36256.000 & 185.664 \\
\hline GPSKDSQR & 6.865 & 11.829 & 0.000 & 49.000 & 17966.000 & 139.922 \\
\hline NOCDHH & 6.641 & 3.381 & 0.000 & 36.000 & 17380.000 & 11.434 \\
\hline NCDHSQR & 55.535 & 90.870 & 0.000 & 1296.000 & 145336.000 & 8257.446 \\
\hline TYPMRR2 & 0.227 & 0.419 & 0.000 & 1.000 & 595.000 & 0.176 \\
\hline GTYPMRR2 & 0.110 & 0.313 & 0.000 & 1.000 & 288.000 & 0.098 \\
\hline MARIT2 & 0.052 & 0.223 & 0.000 & 1.000 & 137.000 & 0.050 \\
\hline GMARIT2 & 0.029 & 0.169 & 0.000 & 1.000 & 77.000 & 0.029 \\
\hline
\end{tabular}




$\begin{array}{lrrrrrr} & \text { MEAN } & \text { STD DEV } & \text { MIN } & \text { MAX } & \text { SUM } & \text { VARIANCE } \\ \text { MARIT3 } & & & & & & \\ \text { GMARIT3 } & 0.081 & 0.272 & 0.000 & 1.000 & 211.000 & 0.074 \\ \text { MARIT4 } & 0.036 & 0.187 & 0.000 & 1.000 & 95.000 & 0.035 \\ \text { GMARIT4 } & 0.019 & 0.137 & 0.000 & 1.000 & 50.000 & 0.019 \\ \text { HDPRIM } & 0.707 & 0.455 & 0.000 & 1.000 & 1849.000 & 0.207 \\ \text { GHDPRIM } & 0.344 & 0.475 & 0.000 & 1.000 & 901.000 & 0.226 \\ \text { SPOPRIM } & 0.451 & 0.498 & 0.000 & 1.000 & 1179.000 & 0.248 \\ \text { GSPOPRIM } & 0.219 & 0.414 & 0.000 & 1.000 & 574.000 & 0.171 \\ \text { ILLIT3 } & 0.212 & 0.409 & 0.000 & 1.000 & 555.000 & 0.167 \\ \text { AGEKID } & 22.319 & 7.842 & 11.000 & 55.000 & 58409.000 & 61.496 \\ \text { TRIBE214 } & 0.007 & 0.085 & 0.000 & 1.000 & 19.000 & 0.007 \\ \text { TRIBE233 } & 0.012 & 0.108 & 0.000 & 1.000 & 31.000 & 0.012 \\ \text { TRIBE234 } & 0.015 & 0.120 & 0.000 & 1.000 & 38.000 & 0.014 \\ \text { TRIBE242 } & 0.028 & 0.164 & 0.000 & 1.000 & 72.000 & 0.027\end{array}$

Table A2: Full Regression Results for Whether the Child has Enrolled in Primary School or not

\begin{tabular}{|c|c|c|c|}
\hline Parameter & Estimate & Standard Error & t-statistic \\
\hline $\mathrm{C}$ & 3.02292 & 1.02714 & 2.94304 \\
\hline VILL & -0.5678 & 0.435253 & -1.30453 \\
\hline VILL3 & -0.68173 & 0.900588 & -0.75699 \\
\hline GVILL3 & -1.88713 & 0.969488 & -1.94652 \\
\hline VILL5 & -1.10195 & 0.537812 & -2.04895 \\
\hline VILL7 & 0.135209 & 0.718818 & 0.188099 \\
\hline VILL8 & 1.02837 & 1.08046 & 0.951795 \\
\hline GVILL8 & -2.30695 & 1.22533 & -1.88272 \\
\hline VILL9 & -1.40914 & 0.470122 & -2.99738 \\
\hline VILL10 & 1.11982 & 1.08871 & 1.02857 \\
\hline GVILL10 & -2.43856 & 1.16058 & -2.10115 \\
\hline VILL11 & 1.12186 & 1.04941 & 1.06903 \\
\hline VILL12 & -1.62982 & 0.722087 & -2.25709 \\
\hline GVILL12 & -1.07158 & 0.918738 & -1.16636 \\
\hline VILL13 & -0.67885 & 0.861672 & -0.78783 \\
\hline VILL14 & -0.09265 & 0.76648 & -0.12087 \\
\hline GVILL14 & -1.54346 & 0.873597 & -1.76678 \\
\hline VILL15 & 0.140519 & 0.676268 & 0.207786 \\
\hline KIDSEX & 1.95689 & 0.863711 & 2.26567 \\
\hline AGEHD & 0.010092 & 0.019239 & 0.52453 \\
\hline HEADSEX & 0.601096 & 0.521153 & 1.1534 \\
\hline ISLAM & 0.602424 & 0.54364 & 1.10813 \\
\hline GISLAM & -0.51556 & 0.658608 & -0.78281 \\
\hline PAGAN & -0.56423 & 0.560547 & -1.00657 \\
\hline GPAGAN & -0.21874 & 0.720804 & -0.30347 \\
\hline OCCHD2 & -1.09659 & 0.524422 & -2.09104 \\
\hline GOCCHD2 & 0.30466 & 0.675087 & 0.45129 \\
\hline OCCHD3 & 0.512294 & 0.842296 & 0.608211 \\
\hline GOCCHD3 & 1.40202 & 1.34982 & 1.03868 \\
\hline OCCHD4 & 0.117685 & 0.823526 & 0.142904 \\
\hline GOCCHD4 & 0.618879 & 1.15044 & 0.53795 \\
\hline OCCHD5 & -0.81233 & 0.799602 & -1.01592 \\
\hline GOCCHD5 & 0.889135 & 0.973975 & 0.912894 \\
\hline POSKID & 0.204619 & 0.341597 & 0.599009 \\
\hline GPOSKD & -0.90192 & 0.489966 & -1.84077 \\
\hline
\end{tabular}




$\begin{array}{lrrr}\text { Parameter } & \text { Estimate } & \text { Standard Error } & \text { t-statistic } \\ & & & \\ \text { PSKDSQR } & -0.04412 & 0.044286 & -0.99626 \\ \text { GPSKDSQR } & 0.129803 & 0.065917 & 1.96919 \\ \text { NOCDHH } & 0.227677 & 0.06733 & 3.38148 \\ \text { NCDHSQR } & -6.83 \mathrm{E}-03 & 2.19 \mathrm{E}-03 & -3.11629 \\ \text { TYPMRR2 } & 0.182072 & 0.409313 & 0.444824 \\ \text { GTYPMRR2 } & -1.07408 & 0.521374 & -2.06009 \\ \text { MARIT2 } & 1.40204 & 1.18905 & 1.17912 \\ \text { GMARIT2 } & -1.83106 & 1.24708 & -1.46828 \\ \text { MARIT3 } & 0.195613 & 0.664002 & 0.294597 \\ \text { GMARIT3 } & -0.19114 & 0.781535 & -0.24458 \\ \text { MARIT4 } & 1.04924 & 0.988779 & 1.06114 \\ \text { GMARIT4 } & -0.28 & 1.10791 & -0.25273 \\ \text { HDPRIM } & 1.29251 & 0.416432 & 3.10377 \\ \text { GHDPRIM } & -0.8046 & 0.506068 & -1.5899 \\ \text { SPOPRIM } & 0.389445 & 0.442194 & 0.88071 \\ \text { GSPOPRIM } & 0.953007 & 0.594193 & 1.60387 \\ \text { ILLIT3 } & -0.66639 & 0.267687 & -2.48942 \\ \text { AGEKID } & -0.07723 & 0.02277 & -3.39162 \\ \text { TRIBE214 } & -1.71203 & 0.833393 & -2.05429 \\ \text { TRIBE233 } & -1.34668 & 1.04775 & -1.28531 \\ \text { TRIBE234 } & -0.15969 & 1.19681 & -0.13343 \\ \text { TRIBE242 } & -0.1219 & 1.08183 & -0.11268\end{array}$

Predicted Outcomes

\begin{tabular}{lcc}
\hline & Enrol & Do not enrol \\
\hline & & \\
Actual & 2470 & 147 \\
Correct Predictions & 2429 & 47 \\
\hline
\end{tabular}

assumes if fitted probability is greater than 0.7 child will complete

Table A3: Descriptive Statistics for the Completion Regression

$\begin{array}{lrrrrrr} & \text { MEAN } & \text { STD DEV } & \text { MIN } & \text { MAX } & \text { SUM } & \text { VARIANCE } \\ \text { ENDKID } & 0.89662 & 0.30453 & 0 & 1 & 1726 & 0.092738 \\ \text { C } & 1 & 0 & 1 & 1 & 1925 & 0 \\ \text { VILL } & 0.097143 & 0.29623 & 0 & 1 & 187 & 0.087752 \\ \text { VILL3 } & 0.065455 & 0.24739 & 0 & 1 & 126 & 0.061202 \\ \text { VILL4 } & 0.088831 & 0.28457 & 0 & 1 & 171 & 0.080982 \\ \text { GVILL4 } & 0.041039 & 0.19843 & 0 & 1 & 79 & 0.039375 \\ \text { VILL5 } & 0.040519 & 0.19723 & 0 & 1 & 78 & 0.038898 \\ \text { GVILL5 } & 0.016623 & 0.12789 & 0 & 1 & 32 & 0.016356 \\ \text { VILL6 } & 0.050909 & 0.21987 & 0 & 1 & 98 & 0.048342 \\ \text { VILL7 } & 0.095065 & 0.29338 & 0 & 1 & 183 & 0.086072 \\ \text { VILL8 } & 0.044156 & 0.20549 & 0 & 1 & 85 & 0.042228 \\ \text { VILL9 } & 0.090909 & 0.28755 & 0 & 1 & 175 & 0.082688 \\ \text { VILL10 } & 0.081558 & 0.27376 & 0 & 1 & 157 & 0.074946\end{array}$




\section{MEAN STD DEV MIN MAX SUM VARIANCE}

\begin{tabular}{|c|c|c|c|c|c|c|}
\hline VILL11 & 0.071169 & 0.25717 & 0 & 1 & 137 & 0.066138 \\
\hline VILL12 & 0.032727 & 0.17797 & 0 & 1 & 63 & 0.031673 \\
\hline VILL13 & 0.020779 & 0.14268 & 0 & 1 & 40 & 0.020358 \\
\hline VILL14 & 0.056623 & 0.23118 & 0 & 1 & 109 & 0.053445 \\
\hline GVILL14 & 0.028571 & 0.16664 & 0 & 1 & 55 & 0.02777 \\
\hline VILL15 & 0.051948 & 0.22198 & 0 & 1 & 100 & 0.049275 \\
\hline GVILL15 & 0.029091 & 0.16811 & 0 & 1 & 56 & 0.028259 \\
\hline VILL16 & 0.058701 & 0.23513 & 0 & 1 & 113 & 0.055284 \\
\hline AGEHD & 54.44987 & 8.86437 & 32 & 86 & 104816 & 78.57714 \\
\hline GAGEHD & 26.92779 & 27.89104 & 0 & 86 & 51836 & 777.91006 \\
\hline HEADSEX & 0.16312 & 0.36957 & 0 & 1 & 314 & 0.13658 \\
\hline GHEADSEX & 0.081039 & 0.27297 & 0 & 1 & 156 & 0.07451 \\
\hline MUSLIM & 0.14857 & 0.35576 & 0 & 1 & 286 & 0.12656 \\
\hline GMUSLIM & 0.070649 & 0.2563 & 0 & 1 & 136 & 0.065692 \\
\hline PAGAN & 0.051429 & 0.22093 & 0 & 1 & 99 & 0.048809 \\
\hline GPAGAN & 0.024416 & 0.15438 & 0 & 1 & 47 & 0.023832 \\
\hline OCCHD2 & 0.041039 & 0.19843 & 0 & 1 & 79 & 0.039375 \\
\hline GOCCHD2 & 0.018182 & 0.13364 & 0 & 1 & 35 & 0.017861 \\
\hline OCCHD3 & 0.054026 & 0.22613 & 0 & 1 & 104 & 0.051134 \\
\hline GOCCHD3 & 0.028571 & 0.16664 & 0 & 1 & 55 & 0.02777 \\
\hline OCCHD4 & 0.073247 & 0.26061 & 0 & 1 & 141 & 0.067917 \\
\hline GOCCHD4 & 0.032208 & 0.1766 & 0 & 1 & 62 & 0.031187 \\
\hline OCCHD5 & 0.038442 & 0.19231 & 0 & 1 & 74 & 0.036983 \\
\hline GOCCHD5 & 0.015584 & 0.12389 & 0 & 1 & 30 & 0.01535 \\
\hline POSKID & 2.99532 & 1.73908 & 1 & 7 & 5766 & 3.02441 \\
\hline GPOSKD & 1.50494 & 1.94589 & 0 & 7 & 2897 & 3.78649 \\
\hline PSKDSQR & 11.99481 & 12.63772 & 1 & 49 & 23090 & 159.71203 \\
\hline GPSKDSQR & 6.04935 & 10.7742 & 0 & 49 & 11645 & 116.08332 \\
\hline NOCDHH & 6.58338 & 2.82124 & 0 & 36 & 12673 & 7.95939 \\
\hline NCDHSQR & 51.2961 & 55.28072 & 0 & 1296 & 98745 & 3055.958 \\
\hline TYPMRR & 0.22649 & 0.41867 & 0 & 1 & 436 & 0.17529 \\
\hline GTYPMRR & 0.11013 & 0.31313 & 0 & 1 & 212 & 0.098052 \\
\hline MARIT2 & 0.050909 & 0.21987 & 0 & 1 & 98 & 0.048342 \\
\hline GMARIT2 & 0.028052 & 0.16516 & 0 & 1 & 54 & 0.027279 \\
\hline MARIT3 & 0.088831 & 0.28457 & 0 & 1 & 171 & 0.080982 \\
\hline GMARIT3 & 0.04 & 0.19601 & 0 & 1 & 77 & 0.03842 \\
\hline MARIT4 & 0.036883 & 0.18852 & 0 & 1 & 71 & 0.035541 \\
\hline GMARIT4 & 0.01974 & 0.13914 & 0 & 1 & 38 & 0.019361 \\
\hline HDPRIM & 0.71584 & 0.45113 & 0 & 1 & 1378 & 0.20352 \\
\hline GHDPRIM & 0.35221 & 0.47778 & 0 & 1 & 678 & 0.22828 \\
\hline HDSEC & 0.075325 & 0.26398 & 0 & 1 & 145 & 0.069687 \\
\hline GHDSEC & 0.035844 & 0.18595 & 0 & 1 & 69 & 0.034577 \\
\hline SPOPRIM & 0.4561 & 0.4982 & 0 & 1 & 878 & 0.2482 \\
\hline GSPOPRIM & 0.22649 & 0.41867 & 0 & 1 & 436 & 0.17529 \\
\hline SPOSEC & 0.019221 & 0.13734 & 0 & 1 & 37 & 0.018861 \\
\hline GSPOSEC & 0.0093506 & 0.096271 & 0 & 1 & 18 & 0.009268 \\
\hline ILLIT & 0.19948 & 0.39971 & 0 & 1 & 384 & 0.15977 \\
\hline AGEKID & 24.36571 & 6.792 & 15 & 55 & 46904 & 46.13126 \\
\hline TRIBE10 & 0.0083117 & 0.090812 & 0 & 1 & 16 & 0.0082469 \\
\hline TRIBE14 & 0.0067532 & 0.081921 & 0 & 1 & 13 & 0.0067111 \\
\hline TRIBE33 & 0.013506 & 0.11546 & 0 & 1 & 26 & 0.013331 \\
\hline TRIBE34 & 0.015584 & 0.12389 & 0 & 1 & 30 & 0.01535 \\
\hline TRIBE42 & 0.021299 & 0.14442 & 0 & 1 & 41 & 0.020856 \\
\hline
\end{tabular}


Table A4: Full Regression Results for Completion at Primary

\begin{tabular}{|c|c|c|c|}
\hline Parameter & Estimate & Standard Error & t-statistic \\
\hline $\mathrm{C}$ & 2.12729 & 0.790009 & 2.69274 \\
\hline VILL & 0.891179 & 0.520768 & 1.71128 \\
\hline VILL3 & -1.83603 & 0.482382 & -3.80618 \\
\hline VILL4 & 0.634906 & 0.850214 & 0.74676 \\
\hline GVILL4 & 0.942597 & 1.27692 & 0.738179 \\
\hline VILL5 & -1.6982 & 0.647845 & -2.62131 \\
\hline GVILL5 & 2.11976 & 0.845814 & 2.50618 \\
\hline VILL6 & 1.52706 & 0.845392 & 1.80633 \\
\hline VILL7 & -0.981214 & 0.504328 & -1.94559 \\
\hline VILL8 & 0.092825 & 0.485218 & 0.191306 \\
\hline VILL9 & -1.3335 & 0.471094 & -2.83064 \\
\hline VILL10 & -0.062317 & 0.5086 & -0.122526 \\
\hline VILL11 & -0.181203 & 0.48965 & -0.370067 \\
\hline VILL12 & -0.171662 & 0.66118 & -0.25963 \\
\hline VILL13 & -1.68041 & 0.612416 & -2.7439 \\
\hline VILL14 & -0.869664 & 0.599884 & -1.44972 \\
\hline GVILL14 & 0.693217 & 0.672561 & 1.03071 \\
\hline VILL15 & -0.965704 & 0.6349 & -1.52103 \\
\hline GVILL15 & 2.59381 & 1.15578 & 2.24421 \\
\hline VILL16 & 0.063835 & 0.548723 & 0.116334 \\
\hline AGEHD & 0.024685 & 0.01766 & 1.39781 \\
\hline GAGEHD & -0.019353 & 0.010964 & -1.76523 \\
\hline HEADSEX & 0.99003 & 0.506523 & 1.95456 \\
\hline GHEADSEX & -0.644607 & 0.686212 & -0.93937 \\
\hline MUSLIM & -0.688251 & 0.350199 & -1.96531 \\
\hline GMUSLIM & 1.00975 & 0.476165 & 2.12058 \\
\hline PAGAN & 0.208042 & 0.573856 & 0.362534 \\
\hline GPAGAN & -0.239812 & 0.777185 & -0.308565 \\
\hline OCCHD2 & 0.178166 & 0.59341 & 0.30024 \\
\hline GOCCHD2 & -0.41075 & 0.817848 & -0.502233 \\
\hline OCCHD3 & 0.655122 & 0.615341 & 1.06465 \\
\hline GOCCHD3 & -1.13119 & 0.743286 & -1.52188 \\
\hline OCCHD4 & -0.023709 & 0.471475 & -0.050286 \\
\hline GOCCHD4 & 0.959965 & 0.909452 & 1.05554 \\
\hline OCCHD5 & -0.093238 & 0.485222 & -0.192156 \\
\hline GOCCHD5 & 0.826949 & 0.782334 & 1.05703 \\
\hline POSKID & -0.478546 & 0.289075 & -1.65544 \\
\hline GPOSKD & 0.065298 & 0.372131 & 0.175471 \\
\hline PSKDSQR & 0.061261 & 0.040986 & 1.49468 \\
\hline GPSKDSQR & $-7.21 \mathrm{E}-03$ & 0.052871 & -0.13635 \\
\hline NOCDHH & 0.123954 & 0.091808 & 1.35015 \\
\hline NCDHSQR & $1.52 \mathrm{E}-04$ & $5.49 \mathrm{E}-03$ & 0.027784 \\
\hline TYPMRR & 0.042342 & 0.323477 & 0.130898 \\
\hline GTYPMRR & 0.361616 & 0.447027 & 0.808935 \\
\hline MARIT2 & -0.738098 & 0.557056 & -1.325 \\
\hline GMARIT2 & 0.295923 & 0.751374 & 0.393842 \\
\hline MARIT3 & -0.655459 & 0.517147 & -1.26745 \\
\hline GMARIT3 & 0.477705 & 0.714468 & 0.668616 \\
\hline MARIT4 & -0.067407 & 0.790718 & -0.085248 \\
\hline GMARIT4 & -0.214635 & 1.0247 & -0.209462 \\
\hline HDPRIM & 0.427732 & 0.311919 & 1.37129 \\
\hline
\end{tabular}




$\begin{array}{lrrr}\text { Parameter } & \text { Estimate } & \text { Standard Error } & \text { t-statistic } \\ & & & \\ \text { GHDPRIM } & 0.382923 & 0.368735 & 1.03848 \\ \text { HDSEC } & -0.355215 & 0.562704 & -0.631264 \\ \text { GHDSEC } & 1.16956 & 0.958936 & 1.21965 \\ \text { SPOPRIM } & 0.812322 & 0.319138 & 2.54536 \\ \text { GSPOPRIM } & -0.240981 & 0.418647 & -0.575618 \\ \text { SPOSEC } & 0.207114 & 1.10488 & 0.187455 \\ \text { GSPOSEC } & 0.182542 & 1.60035 & 0.114064 \\ \text { ILLIT } & -0.173564 & 0.246092 & -0.705281 \\ \text { AGEKID } & -0.047975 & 0.020968 & -2.28802 \\ \text { TRIBE10 } & 0.821163 & 1.09015 & 0.753257 \\ \text { TRIBE14 } & 0.256478 & 1.12869 & 0.227234 \\ \text { TRIBE33 } & 0.149645 & 0.667037 & 0.224343 \\ \text { TRIBE34 } & 1.38438 & 1.09195 & 1.2678 \\ \text { TRIBE42 } & 0.533074 & 1.09282 & 0.487795\end{array}$

Predicted Outcomes

\begin{tabular}{lcc}
\hline & Complete Primary & $\begin{array}{c}\text { Do not complete } \\
\text { Primary }\end{array}$ \\
\hline Actual & 1726 & 199 \\
Correct Predictions & 1653 & 45 \\
\hline
\end{tabular}

assumes if fitted probability is greater than 0.7 child will complete

Table A5: Descriptive Statistics for the Secondary Enrolment Regression

C

VILL2

VILL3

VILL4

VILL5

VILL6

VILL7

VILL8

GVILL8

VILL9

VILL10

GVILL10

VILL1 1

VILL12

VILL13

GVILL13

VILL14

VILL15

$\begin{array}{rr}\text { MEAN } & \text { STD DEV MIN } \\ 1 & 0 \\ 0.10255 & 0.30346 \\ 0.053882 & 0.22585 \\ 0.097335 & 0.2965 \\ 0.039397 & 0.1946 \\ 0.05562 & 0.22925 \\ 0.093279 & 0.29091 \\ 0.043453 & 0.20393 \\ 0.021437 & 0.14488 \\ 0.086327 & 0.28093 \\ 0.084589 & 0.27835 \\ 0.039397 & 0.1946 \\ 0.072422 & 0.25926 \\ 0.033604 & 0.18026 \\ 0.017961 & 0.13285 \\ 0.0063731 & 0.0796 \\ 0.051564 & 0.22121 \\ 0.054461 & 0.22699\end{array}$

MAX
1
0
0
0
0
0
0
0
0
0
0
0
0
0
0
0
0
0

\begin{tabular}{lrr}
\multicolumn{2}{c}{ SUM } & \multicolumn{2}{l}{ VARIANCE } \\
1 & 1726 & 0 \\
1 & 177 & 0.092086 \\
1 & 93 & 0.051008 \\
1 & 168 & 0.087912 \\
1 & 68 & 0.037867 \\
1 & 96 & 0.052557 \\
1 & 161 & 0.084627 \\
1 & 75 & 0.041589 \\
1 & 37 & 0.020989 \\
1 & 149 & 0.07892 \\
1 & 146 & 0.077478 \\
1 & 68 & 0.037867 \\
1 & 125 & 0.067216 \\
1 & 58 & 0.032493 \\
1 & 31 & 0.017648 \\
1 & 11 & 0.0063362 \\
1 & 89 & 0.048934 \\
1 & 94 & 0.051525
\end{tabular}


MEAN STD DEV MIN MAX SUM VARIANCE

\begin{tabular}{|c|c|c|c|c|c|c|}
\hline VILL16 & 0.061414 & 0.24016 & 0 & 1 & 106 & 0.057675 \\
\hline GVILL16 & 0.02781 & 0.16448 & 0 & 1 & 48 & 0.027052 \\
\hline AGEHD & 54.43105 & 8.89583 & 32 & 86 & 93948 & 79.13582 \\
\hline GAGEHD & 26.6321 & 27.85192 & 0 & 86 & 45967 & 775.7295 \\
\hline HEADSEX & 0.15643 & 0.36337 & 0 & 1 & 270 & 0.13204 \\
\hline GHEADSEX & 0.073581 & 0.26116 & 0 & 1 & 127 & 0.068206 \\
\hline MUSLIM & 0.14253 & 0.34969 & 0 & 1 & 246 & 0.12228 \\
\hline GMUSLIM & 0.070104 & 0.2554 & 0 & 1 & 121 & 0.065227 \\
\hline PAGAN & 0.047509 & 0.21279 & 0 & 1 & 82 & 0.045278 \\
\hline GPAGAN & 0.021437 & 0.14488 & 0 & 1 & 37 & 0.020989 \\
\hline OCCHD2 & 0.039977 & 0.19596 & 0 & 1 & 69 & 0.038401 \\
\hline GOCCHD2 & 0.017381 & 0.13072 & 0 & 1 & 30 & 0.017089 \\
\hline OCCHD3 & 0.052144 & 0.22238 & 0 & 1 & 90 & 0.049453 \\
\hline GOCCHD3 & 0.026072 & 0.1594 & 0 & 1 & 45 & 0.025407 \\
\hline OCCHD4 & 0.075898 & 0.26491 & 0 & 1 & 131 & 0.070178 \\
\hline GOCCHD4 & 0.034762 & 0.18323 & 0 & 1 & 60 & 0.033573 \\
\hline OCCHD5 & 0.034762 & 0.18323 & 0 & 1 & 60 & 0.033573 \\
\hline GOCCHD5 & 0.015064 & 0.12184 & 0 & 1 & 26 & 0.014845 \\
\hline POSKID & 3.00985 & 1.75497 & 1 & 7 & 5195 & 3.0799 \\
\hline GPOSKID & 1.4971 & 1.95329 & 0 & 7 & 2584 & 3.81535 \\
\hline PSKDSQR & 12.13731 & 12.80599 & 1 & 49 & 20949 & 163.99331 \\
\hline GPSKDSQR & 6.05446 & 10.86179 & 0 & 49 & 10450 & 117.97848 \\
\hline NOCDHH & 6.64253 & 2.83952 & 1 & 36 & 11465 & 8.06286 \\
\hline NCDHSQR & 52.18134 & 57.08609 & 1 & 1296 & 90065 & 3258.8222 \\
\hline TYPMRR & 0.22711 & 0.41909 & 0 & 1 & 392 & 0.17564 \\
\hline GTYPMRR & 0.11124 & 0.31452 & 0 & 1 & 192 & 0.098923 \\
\hline MARIT2 & 0.044612 & 0.20651 & 0 & 1 & 77 & 0.042646 \\
\hline GMARIT2 & 0.023754 & 0.15233 & 0 & 1 & 41 & 0.023204 \\
\hline MARIT3 & 0.086327 & 0.28093 & 0 & 1 & 149 & 0.07892 \\
\hline GMARIT3 & 0.03708 & 0.18901 & 0 & 1 & 64 & 0.035726 \\
\hline MARIT4 & 0.034183 & 0.18175 & 0 & 1 & 59 & 0.033034 \\
\hline GMARIT4 & 0.017381 & 0.13072 & 0 & 1 & 30 & 0.017089 \\
\hline HDPRIM & 0.73407 & 0.44196 & 0 & 1 & 1267 & 0.19533 \\
\hline GHDPRIM & 0.36153 & 0.48058 & 0 & 1 & 624 & 0.23096 \\
\hline HDSEC & 0.079954 & 0.2713 & 0 & 1 & 138 & 0.073604 \\
\hline GHDSEC & 0.038818 & 0.19322 & 0 & 1 & 67 & 0.037333 \\
\hline SPOPRIM & 0.47509 & 0.49952 & 0 & 1 & 820 & 0.24952 \\
\hline GSPOPRIM & 0.23638 & 0.42498 & 0 & 1 & 408 & 0.18061 \\
\hline SPOSEC & 0.020278 & 0.14099 & 0 & 1 & 35 & 0.019878 \\
\hline GSPOSEC & 0.0098494 & 0.098783 & 0 & 1 & 17 & 0.009758 \\
\hline ILLIT & 0.18772 & 0.3906 & 0 & 1 & 324 & 0.15257 \\
\hline AGEKID & 24.27057 & 6.6435 & 15 & 55 & 41891 & 44.13603 \\
\hline TRIBE10 & 0.0086906 & 0.092844 & 0 & 1 & 15 & 0.0086201 \\
\hline TRIBE14 & 0.0069525 & 0.083115 & 0 & 1 & 12 & 0.0069082 \\
\hline TRIBE33 & 0.012746 & 0.11221 & 0 & 1 & 22 & 0.012591 \\
\hline TRIBE34 & 0.016802 & 0.12857 & 0 & 1 & 29 & 0.016529 \\
\hline TRIBE42 & 0.023175 & 0.1505 & 0 & 1 & 40 & 0.022651 \\
\hline
\end{tabular}


Table A6: Full Regression Results for Secondary Attendance

\begin{tabular}{|c|c|c|c|}
\hline Parameter & Estimate & Standard Error & $\overline{\text { t-statistic }}$ \\
\hline $\mathrm{C}$ & -3.89558 & 0.721777 & $\overline{-5.39721}$ \\
\hline VILL2 & -3.14084 & 0.395008 & -7.95133 \\
\hline VILL3 & -2.69679 & 0.465809 & -5.78947 \\
\hline VILL4 & -3.0158 & 0.412084 & -7.31841 \\
\hline VILL5 & -2.463 & 0.5236 & -4.70398 \\
\hline VILL6 & -1.60673 & 0.419966 & -3.82586 \\
\hline VILL7 & -1.97983 & 0.401903 & -4.92614 \\
\hline VILL8 & -1.51441 & 0.538872 & -2.81033 \\
\hline GVILL8 & -0.157002 & 0.774168 & -0.202801 \\
\hline VILL9 & -0.866319 & 0.365053 & -2.37313 \\
\hline VILL10 & -2.60069 & 0.446754 & -5.8213 \\
\hline GVILL10 & 1.29137 & 0.465606 & 2.77353 \\
\hline VILL11 & -1.95261 & 0.371569 & -5.25503 \\
\hline VILL12 & -2.27289 & 0.55186 & -4.1186 \\
\hline VILL13 & -1.45671 & 0.648357 & -2.24677 \\
\hline GVILL13 & 1.01933 & 0.912886 & 1.1166 \\
\hline VILL14 & -1.62367 & 0.417637 & -3.88776 \\
\hline VILL15 & -1.43058 & 0.3852 & -3.71386 \\
\hline VILL16 & -0.568225 & 0.408205 & -1.39201 \\
\hline GVILL16 & -0.766328 & 0.484667 & -1.58114 \\
\hline AGEHD & 0.021438 & 0.013716 & 1.56305 \\
\hline GAGEHD & $-5.99 \mathrm{E}-03$ & $8.66 \mathrm{E}-03$ & -0.691687 \\
\hline HEADSEX & 0.410504 & 0.393162 & 1.04411 \\
\hline GHEADSEX & 0.404817 & 0.560896 & 0.721733 \\
\hline MUSLIM & -0.615654 & 0.31548 & -1.95149 \\
\hline GMUSLIM & 0.569545 & 0.401312 & 1.41921 \\
\hline PAGAN & -1.42101 & 0.588613 & -2.41417 \\
\hline GPAGAN & -0.255768 & 0.979913 & -0.26101 \\
\hline OCCHD2 & 0.279333 & 0.489885 & 0.570201 \\
\hline GOCCHD2 & -0.644468 & 0.7384 & -0.87279 \\
\hline OCCHD3 & 0.354001 & 0.394866 & 0.896509 \\
\hline GOCCHD3 & 0.4122 & 0.575273 & 0.716529 \\
\hline OCCHD4 & 0.30747 & 0.325136 & 0.945664 \\
\hline GOCCHD4 & 0.076152 & 0.47844 & 0.159168 \\
\hline OCCHD5 & 0.137329 & 0.486048 & 0.282543 \\
\hline GOCCHD5 & 0.591689 & 0.647493 & 0.913815 \\
\hline POSKID & $-6.89 \mathrm{E}-03$ & 0.201191 & -0.03427 \\
\hline GPOSKID & -0.247276 & 0.27882 & -0.886866 \\
\hline PSKDSQR & $-1.88 \mathrm{E}-03$ & 0.027089 & -0.069299 \\
\hline GPSKDSQR & 0.05194 & 0.037602 & 1.38131 \\
\hline NOCDHH & 0.40566 & 0.108042 & 3.75466 \\
\hline NCDHSQR & -0.019886 & $6.75 \mathrm{E}-03$ & -2.94431 \\
\hline TYPMRR & 0.12374 & 0.236 & 0.524324 \\
\hline GTYPMRR & -0.601062 & 0.336253 & -1.78753 \\
\hline MARIT2 & 0.03173 & 0.495499 & 0.064036 \\
\hline GMARIT2 & 0.117876 & 0.699281 & 0.168567 \\
\hline MARIT3 & 0.384311 & 0.394622 & 0.973872 \\
\hline GMARIT3 & -0.971469 & 0.596957 & -1.62737 \\
\hline MARIT4 & 0.092808 & 0.714801 & 0.129838 \\
\hline GMARIT4 & -1.8709 & 1.32161 & -1.41562 \\
\hline HDPRIM & 0.162759 & 0.251289 & 0.647697 \\
\hline GHDPRIM & -0.188736 & 0.316892 & -0.595585 \\
\hline HDSEC & 0.925142 & 0.321017 & 2.88191 \\
\hline GHDSEC & 0.27086 & 0.448923 & 0.603354 \\
\hline SPOPRIM & 0.079274 & 0.223375 & 0.354891 \\
\hline
\end{tabular}




\begin{tabular}{lrrr}
\multicolumn{1}{r}{ Parameter } & Estimate & Standard Error & t-statistic \\
& & & \\
GSPOPRIM & 0.521177 & 0.308803 & 1.68773 \\
SPOSEC & 0.412622 & 0.560993 & 0.735521 \\
GSPOSEC & 0.588354 & 0.792106 & 0.742772 \\
ILLIT & -0.446218 & 0.226498 & -1.97007 \\
AGEKID & 0.069762 & 0.015988 & 4.3633 \\
TRIBE10 & 1.06722 & 0.635509 & 1.67931 \\
TRIBE14 & 1.06741 & 0.820545 & 1.30086 \\
TRIBE33 & -0.724512 & 0.831128 & -0.871721 \\
TRIBE34 & 0.540326 & 0.504657 & 1.07068 \\
TRIBE42 & 0.631066 & 0.432644 & 1.45863
\end{tabular}

Predicted Outcomes

\begin{tabular}{lcc}
\hline & Enrol in Secondary & $\begin{array}{l}\text { Do not enrol in } \\
\text { Secondary }\end{array}$ \\
\hline & & 1267 \\
Actual & 459 & 1177 \\
Correct Predictions & 152 & \\
\hline
\end{tabular}

assumes if fitted probability is greater than 0.5 will enrol 


\section{Bibliography}

Appleton, S., Collier, P. and Horsnell, P., 1990, 'Gender, Education, and Employment in Cote d'Ivoire', SDA Working Paper Series No 8, Washington: World Bank

Becker, G.S., 1981, A Treatise on the Family, Cambridge, MA: Harvard University Press

Cameron, J., and Dodd, W.H., 1970, Schools, Society and Progress in Tanzania, Oxford: Pergamon Press

Chernichovsky, D., 1985, 'Socioeconomic and Demographic Aspects of School Enrolment and Attendance in Rural Botswana', Economic Development and Cultural Change, Vol 33 No2:319-332

Collier, P., Radwan, S., and Wangwe, S., Labour and Poverty in Rural Tanzania, Oxford: Clarendon

Cooksey, B., Galabawa, J., Ishumi, G., and Malekela, G., 1991, 'A survey of living and working conditions of primary and secondary school teachers', Dar es Salaam

Durasaimy, P., 1992, 'Gender, Intrafamily Allocation of Resources and Child Schooling in South India', Center Discussion Paper No 667, Conneticut: Yale University

Galabawa, J., 1994, 'Characteristics, Financing, Unit Costs and Selection Issues of Non Government Secondary School Provision in Tanzania', Faculty of Education, Department of Planning and Administration, University of Dar es Salaam, World Bank

Greene, W. H.,1993, Econometric Analysis, New York: Macmillan Publishing

Haddad, L., Hoddinot, J., Alderman, H., 1994, Intrahousehold Resource Allocation: An Overview', Policy Research Working Paper No 1255, Washington: World Bank

Hazlewood, A., Armitage J., Berry, A., Knight J., and Sabot, R., 1989, Education, Work and Pay in East Africa, Oxford: Clarendon Press

Hoddinot, J., and L. Haddad, 1991, 'Household Expenditures, Child Anthropometric Status, and the Intrahousehold Division of Income: Evidence from the Cote d'Ivoire', Research Programme in Development Studies Discussion Paper No 155, Princeton, N.J., U.S.A.: Woodrow Wilson School of Public and International Affairs, Princeton University

IDS and MOEC, 1996, 'Gender and Primary Schooling in Tanzania', Brighton, U.K.

Kabeer, N., 1991, 'Gender, Production and Well-Being: Rethinking the Household Economy', IDS Discussion Paper No 288, Brighton:IDS

Kaijage, F., and Tibaijuka, A., 1996, Poverty and social exclusion in Tanzania, International Institute for Labour Studies, United Nations Development Programme, Research Series

Knight J.B., and Sabot, R.H., 1990, Education, Productivity and Inequity: The East African Natural Experiment, A World Bank Research Publication

Maddala, G.S., 1992, Introduction to Econometrics, New York: Macmillan Publishing 
Maddala, G.S., 1983, Limited-Dependent Variables and Qualitative Variables in Econometrics, Cambridge, New York: Cambridge University Press

Malekela, G.A. 1986, 'Socio-Economic Status (SES) Origins: The Case of Tanzania Secondary School Students', Utafiti Vol 8, No 1:67-83

Mason, A.D., and Khandker, S.R., 1995, 'Household schooling decisions in Tanzania', draft, Poverty and Social Policy Department', World Bank: Washington D.C., July

Mbilinyi, M., Mbughuni, P., Meena, R., and Olekambaine, P., 1991, 'Education in Tanzania with a gender perspective', Education Division Documents, No 53, SIDA: Sweden

MOEC, 1995c, Basic Education Statistics in Tanzania (BEST) 1990-1994, Ministry of Education and Culture Dar es Salaam, June

Omari, I.M., 1995, The real issues in Girls Education in Tanzania', Discussion Paper, University of Dar es Salaam, draft

Omari, I.M., and Mosha, H.J., 1987, The Quality of Primary Education In Tanzania, Nairobi: Man Graphics

Parish, W. L. and Willis, R.J., 1993, 'Daughters, Education, and Family Budgets: Taiwan Experiences', Journal of Human Resources, Vol 28 No 4:863-898

Sen, A., 'Gender and Cooperative Conflicts' in I. Tinker (ed), Persistent Inequalities: Women and World Development, New York: Oxford University Press

Sumra, S., 1993, 'Primary education and the urban poor; a study of parental attitudes towards schooling in the Burguruni and Vingungutti wards in Dar es Salaam', a study prepared for PLAN International, Dar es Salaam

Swantz, M. 1985, Women in Development: A Creative Role Denied?, London: St. Martins Press

Tansel, A., 1993, 'School Attainment, Parental Education and Gender in Conte D'Ivoire and Ghana', Center Discussion Paper No 692, Conneticut: Yale University

Tanzania Research Development Group, TADREG, 1993, 'Parents' Attitudes and Strategies Towards Education in Rural Tanzania', March, Dar es Salaam

Tinker, I., 1987, 'Street Foods: Testing Assumptions about Informal Sector Activity by Women and Men', Current Sociology, Vol 35 No3

United Republic of Tanzania, 1995a, Primary Education Master Plan "A Framework", Ministry of Education and Culture Prime Ministers Office, Dar es Salaam

United Republic of Tanzania, 1995b, Basic Education Statistics in Tanzania (BEST) 19901994, Ministry of Education and Culture, Dar es Salaam

United Republic of Tanzania, 1994, The Development of Education: 1993-1994 National Report of the United Republic of Tanzania, Ministry of Educaiton and Culture, Dar es Salaam 
United Republic of Tanzania, 1993, Labour Force Survey - Tanzania Mainland 1990/91,

Bureau of Statistics, Presidents Office, Planning Commission Dar es Salaam and Labour

Department, Ministry of Labour and Youth Development

World Bank, 1995, 'Tanzania Social Sector Review', unpublished report No 14039-TA, Dar es Salaam, Tanzania

World Bank, 1995b African Development Indicators, Washington D. C. 